\title{
ELS OBJECTES DE LA VIDA QUOTIDIANA A LES LLARS BARCELONINES AL COMENÇAMENT DEL SEGLE XIV'
}

\begin{abstract}
L'inventari: entre l'anécdota i la historia real.- Dins de les cases barcelonines. Caixes i recipients. Robes i complements per al cos. Robes i teles per a la llar. Cobertors. El llit i els seus guarniments. Coixins. Taules i seients. Cuina, rebost i els seus complements. Armes $\mathrm{i}$ defensa. Salut, higiene i benastrugança. Objectes de luxe i d'ostentació. Música. Objectes de devoció. Il luminació. Comptabilitat. Balances. Per a la bèstia. Altres objectes.- Pero no a totes les cases.- Apèndix.
\end{abstract}

\section{L'INVENTARI: ENTRE L'ANÈCDOTA I LA HISTÒRIA REAL}

És clar que els inventaris de béns de difunts, realitzats notarialment amb recompte minuciós i detallat de tots els objectes de cara a l'avaluació exacta de l'herència, ens són la via més directa i completa per tal de penetrar a l'interior de les cases dels difunts i conèixer així els objectes entre els quals havien viscut. No hem d'oblidar que aquests objectes formaven part de la vida corrent i quotidiana dels seus posseïdors: són, doncs, amarats de llurs activitats i comportaments més casolans i normals. És en l'apreciació d'aquesta situació on rau el veritable interès que ens ofereixen els inventaris.

Cal no oblidar aquest raonament perquè la lectura d'un inventari, per la seva pròpia estructura - una munió d'objectes-, pot convertir-se en el recull d'anecdotaris, en la citació d'una suma d'objectes més o menys curiosos, més o menys atractiu el seu esment a les nostres oïdes tan allunyades de la societat que generà aquells objectes. I, en canvi, com ho acabo d'apuntar, en els inventaris podem trobar les petges que ens menen al que amb certa gosadia podríem anomenar la història real, la

1 Abreviatures emprades en el present treball: ACA Arxiu de la Corona d'Aragó; ACB Arxiu Capitular de la Catedral de Barcelona; ADPO, Archives Départementales des Pyrénées-Orientales; AHCR Arxiu Històric Comarcal de Reus; AHCT, Arxiu Històric Comarcal de Tortosa; AHMV, Arxiu Històric Municipal de Vic; APSMM Arxiu Parroquial de Santa Maria del Mar; AVV, Arxiu de la Vegueria de Vic; IMHB Institut Municipal d'Història de Barcelona.

Així mateix, vull agrair sincerament la Doctora Carme Batlle, que $m$ 'ha ofert i facilitat el present treball dins del marc del curs de doctorat de la Universitat de Barcelona \&La societat catalana baix- medieval: l'habitatgew, durant l'any 1989-1990. 
que es realitzava entre la cuina $\mathrm{i}$ el dormitori, entre els objectes de treball i els objectes de lleure.

Tot això no és gens nou. La mateixa curiositat que desperten els inventaris ha estat esquer de la seva publicació al llarg de tot el nostre segle, ${ }^{2}$ si bé ens cal avançar fins a dades més recents per trobar no sols reculls d'objectes sinó la seva anàlisi i un afany per penetrar en les formes de vida que donen raó de ser als objectes. ${ }^{3}$

Malgrat tot això, malgrat les moltes possibilitats que ofereix un inventari, ${ }^{4} s^{\prime}$ ha desaprofitat fins ara el seu estudi per a penetrar en un període tan concret com és el començament del segle XIV a la ciutat de Barcelona. Sabem que aquest període és un temps de bonança econòmica, "d'empenta i prosperitat",' amb els grups ciutadans ben assentats en el govern municipal i a prop del rei, ${ }^{6}$ just abans de sentir-se els primers símptomes de davallada econòmica i crisi social i general.' Considero que és interessant poder penetrar a l'interior de les cases barcelonines per tal de conèixer com es vivia realment aquest període, quina era la «història real» d'aquestes

2 Centrant-nos en el període medieval $i$ en el nostre país, podem trobar força inventaris publicats des de començament de segle fins als nostres dies. Podem veure'n l'esment a Teresa-Maria VINYOLES I VIDAL, La casa i l'obrador d'un esmolet de Barcelona a finals del segle XIV, "Cuadernos de Historia Econòmica de Cataluñan, XV (1976), pàg. 9. I hem de completar-lo amb els publicats més recentment, entre els que podem esmentar: Carme BATLLE I GALLART, La Familia i la casa d'un draper de Barcelona, Burget de Banyeres (primera meitat del segle XIII), "Acta Archeologica et Historica Medievalia", II (1981), pàgs. 69-91; Maria Mercè COSTA, L'inventari dels béns del poeta Pere de Queralt, "Miscel.lània Aramon i Serran, III (Barcelona, 1983), pàgs. 115-145; Margarita Tintó i Sala, Inventari dels béns que en Francesc Blanch, degà del Vallès posseïa a la Rectoria de Granollers, any 1464, "Ponències" (Granollers, 1984), pàgs 47-58; Montserrat CASAS NADAL, La casa i els béns de Berenguer Sespluga, rector de Cardona (+1375), «Cardener», III (1986), pàgines 85-100; Carme BATLLE I Angels PARÉS, El castell de Sitges a la mort de Bernat de Fonollar (1326); i Equip BROIDA, Us de l'espai en els castells i torres, a Manuel RIU dir., Castells, guaites, torres $i$ fortaleses de la Catalunya Medieval, "Acta Mediaevalia, Annex d'Arqueologia medieval» III (1986-87), pàgs. 154-177 i 217-293 respectivament; J. TRenCHS ODENA- M. L. MANDIGORRA, La capilla de Pedro el ceremonioso (1356): sus libros, «Boletín de la Sociedad Castellonense de Cultura», LXIII, (1987), pàgs. 581-607; Joan-Eusebi GARCIA I BIOSCA, Un "encant" de la casa dels Sanaüja a Lleida, any 1343, "Palestra Universitària 3» (UNED Cervera, 1988), pàgs. 255-276; Josep PLANA I BORRAs, Inventari dels béns de Bernardó Benet, i Anna PÉREZ I CASTILLO, Notícia d'un inventari de lÁrxiu de la Catedral de Barcelona. (Els béns d'un català a Tebas), a «Homenatge a la memòria del professor Dr. Emilio Sáez», (1989), pàgs. $151-158$ i 139-149 respectivament.

3 Una ullada als articles esmentats a la nota anterior, ens permet constatar de seguida com és entre els estudis efectuats en les darreres dècades on veiem, globalment, més esforços per passar del simple llistat d'objectes a la seva anàlisi.

4 Potser cal veure la reflexió crítica de Núria Sales: Núria SALES, Inventaris Post-mortem, "L'Avenç" 92 (1986), pàgs. 54-57.

5 Carme BATlle, La Barcelona de la Baixa Edat Mitjana, a A. DURAN I SANPERE, director, Història de Barcelona, I, Barcelona, 1975, pàg. 333.

6 Vegeu, per exemple, de manera resumida, aquesta situació a Carme BATLlE, Conèixer la Història de Catalunya, II Del segle XIII al XV, Barcelona, 1983. Pàgs 87-97.

7 Podem veure un resum sobre la gestació de la crisi a Claude CARRÈre, Barcelona, 1380-1462. Un centre econòmic en època de crisi, Barcelona, 1978. Pàgs. 203 i ss. I podem analitzar-ho breument dins del context general europeu de «les crises du XIVe sièclen, en expressió d'E. Perroy, a Bernard GuILLEMAIN, Les transformations du XIVe siècle. Bilan et orientation des recherches, "Cuadernos de Historia. Anexo de la Revista Hispania», VIII (1977), pàgs. 1-14. 
persones que es movien a la capital catalana en un moment on, després d'estudiar-ne els grans paràmetres, tots els autors qualifiquen la ciutat de pròspera i els seus habitants semblen els protagonistes, espectadors i usufructuaris d'un període encara plenament florent.

Tot indica que els inventaris són un bon camí per a aconseguir aquest propòsit. Ara bé, no ens hem de precipitar en aquesta tasca. No n'hi ha prou de llegir un inventari datat els primers anys del segle XIV per creure poder parlar de la vida a l'interior de les cases de Barcelona. És clar que la riquesa que es generava no la devien rebre tots els ciutadans de la mateixa manera, $i$ és evident que fins $i$ tot per a molta gent no existia ni la possibilitat de fer inventaris: si apliquem ja la divisió social que anys després farà Eiximenis, ${ }^{8}$ podem pensar que els que formen el "poble menut» amb prou feines devien posseir béns per a anotar als inventaris, i és clar que no devien tenir gaires motius per inventariar el poc que poguessin deixar en la seva mort.' Així, doncs, cal precisar que, d'entrada, centrem l'estudi en la franja de població on trobarem els menestrals i mercaders que ens configuren la vida urbana. I, com que el que es tracta d'avaluar és precisament la vida de les persones que, en una o altra mesura, participen o col.laboren en l'activitat econòmica urbana d'aleshores, ens quedarem amb ells, que tradicionalment s' han presentat com els elements propis de la vida urbana, i no tractarem de penetrar en la vida dels nobles i clergues que també viuen en aquella Barcelona. ${ }^{10}$

$\mathrm{Amb}$ aquest interès $\mathrm{i}$ aquestes prevencions, $s$ 'ha triat un conjunt, crec que representatiu, d'inventaris de la primera dècada del segle XIV, " amb la pretensió més d'obrir portes que no pas de tancar-les, sobretot després d'haver comprovat que els béns, esmentats lacònicament als inventaris, tan sols cobren vida i els podem dibuixar $i$ conèixer en comparar-los amb altres fonts similars, $i$ tot sabent que la fragmentació social de les fonts i la seva mateixa escassetat no ens permetran potser

8 Francesc EIXIMENIS, al Regiment de la cosa pública (ed. a cura del P. Daniel de MOLINS DE REI, Barcelona, 1927, pàg. 41), divideix la societat en tres grups, que per a L. Cervera és «la defensa de la estructura jeràrquica medieval" (Luís CERVERA, Francisco de Eiximenis y su sociedad urbana ideal, San Lorenzo de El Escorial, 1989, pàg. 158) però altres autors, com $R$. dÁbadal, hi veuen una divisió econòmica (Ramon d'ABADAL, Pedro el Ceremonioso y los comienzos de la decadencia política de Cataluña, a Ramón Menéndez PidAl, Historia de España, XIV, Madrid, 1966, pàg. XX).

9 Sobre la pobresa a la Barcelona baix-medieval es poden veure, entre d'altres, alguns treballs recollits a Manuel RIU, dir. La pobreza y la asistencia a los pobres en la Cataluña medieval "Anejo Anuario de Estudios Medievales" IX i XI (1980 i 1982).

10 Tot i no desconèixer que no podem lligar la vida urbana només amb els grups artesans $\mathrm{i}$ comerciants i que no és facil separar el món urbà del rural, la vida urbana de la vida feudal (vegeu per exemple José Luís MARTín, La sociedad media e inferior de los reinos bispànicos, "Anuario de Estudios Medievales" VII (1971-1972[1973]), pàgs. 556-576; o Julio VALDEON, Los conflictos sociales en los siglos XIV y XV en la Peninsula Ibérica, "Anales de la Universidad de Alicante, História Medieval», III (1984), pàg. 139).

11 Crec que no cal justificar la necessitat de treballar amb un conjunt d'inventaris per tal d'abastar l'objectiu que ens proposem. Podria repetir les paraules de Casas Homs: «Els inventaris no solen ésser bons col.laboradors de la història, presos individualment, perquè d'un a un són el registre d'un moment, d'una situació. És necessària la confluència de com més millor.» (JOSEP MARÍ CASAS HOMS, Interpretació Histórico-Geogràfica d'un inventari medieval, "Miscel.lània Pau Vila», (1975), pàg. 215). 
mai poder realitzar un estudi ben complet d'aquella societat, però sí, i aquest n'és l'objectiu, apropar-nos un xic més al seu coneixement. ${ }^{12}$

\section{DINS DE LES CASES BARCELONINES}

A la planta baixa dels habitatges, hi trobarem les botigues, que són les habitacions destinades a l'obrador o a magatzem de les mercaderies: Jaume Cànoves, per exemple, era mercader i a la planta baixa de casa seva tenia tres botigues, l'una ocupant l'espai de sota l'escala d'accés a l'habitatge, i totes tres plenes de sacs $i$ d'esportes curulles d'espècies. ${ }^{13}$ Els menestrals, és clar, hi tenien l'obrador. No ens hi podem detenir ara, el que ens interessa és la casa del barceloní, no el seu magatzem o el seu taller. ${ }^{14}$ Entrarem, doncs, a l'interior de les llars i les escorcollarem, tot tractant d'observar els diferents objectes en la seva funcionalitat, per tal d'il.luminar la vida diària dels seus posseïdors, sense distingir, en aquest primer moment, el diferent grau d'accés que per diverses raons es pugui tenir als béns.

\section{Caixes $i$ recipients}

Els objectes els trobarem guardats en caixes." Les caixes són uns mobles de fusta, paral.lelepípedes que s'obren per la cara superior, que actua a manera de tapa -cohopertorium-. Són de diferents mides. Una caixa gran, pel que fa a capacitat, ens l'hem d'imaginar com un recipient d'important cabuda, si bé, com és evident, no sempre s'omplen fins dalt. Les formes, en les caixes grans i mitjanes, solen ser bastant semblants, encara que a vegades algunes difereixen: de les moltes caixes de l'esmentat Jaume Cànoves, una va cridar l'atenció del notari que feia l'inventari perquè la va veure «stricta et longa»", ${ }^{16} i$ fins $i$ tot hi ha models concrets, com el que anomenaven "caixa pisanesca», caixa d'un suposat origen pisà en el model i d'una capacitat mitjana-gran. ${ }^{17}$

12 Abans de començar a esgranar l'apropament realitzat a l'interior de les llars barcelonines, $m$ 'és obligat agrair els suggeriments i el generós ajut que he rebut d'en Jaume Riera i Sans.

13 ACB, manual notarial 9, fol. 12 v.- 13 r.

14 Un estudi complet d'un obrador concret, unes dècades posterior als anys en què hem centrat el present treball, el trobem a Teresa-Maria VINYOLES I VIDAL, La casa i l'obrador d'un esmolet de Barcelona a finals del sagle XIV, «Cuadernos de Historia Económica de Cataluña» XV (1976), pàgs 9-49.

15 Documentar cada una de les afirmacions del present treball $i$ justificar la presència dels diferents objectes que aniré esmentant, com sembla que seria més procedent de fer, comportaria un enfarfegament de notes i signatures a peu de pàgina. Per això he cregut més adient afegir un apèndix exposant una selecció d'inventaris, la lectura dels quals mostrara les fonts on han begut les afirmacions expressades en el treball.

16 ACB, Llibre notarial 9, fol. 12 r.

17 Josep Plana i Borràs (Josep PLANA I BORRAs, Inventari dels béns de Bernardó Benet, uHomenatge a la memòria del professor Dr. Emilio Sáezn, (1989), pàg. 154), relaciona la caixa pisanesca amb la tela pisanesca, relació que en principi pot semblar precipitada: sabem que l'evocació pisana està en altres objectes -com el bacinet i la brasserola de l'armadura- que no semblen tenir gaire relació amb la tela. 
Poques vegades ens consta el tipus de fusta amb què s'ha treballat la caixa, però sempre que $s^{\prime}$ indica es tracta de noguer. ${ }^{18}$

Aquestes caixes grans o mitjanes descansen, en llur majoria, directament sobre el terra. Les més preuades són les que tenen potes, i encara fan més goig si tenen la tapa pintada -sovint s'escull, per a pintar-la, el color verd-. I les més valorades són les que tenen potes, mostren la tapa pintada i, a més, presenten decorada la part anterior, decoració que sol consistir en un o dos escuts pintats. ${ }^{19}$

Molt freqüents són els taüts - «tahuts», «atahuts» ${ }^{20}$-, que trobem de característiques molt similars a les caixes grans i mitjanes. L'estructura del moble és molt semblant a les caixes $i$, com aquestes, els trobem amb peus o sense. Pel que fa a la seva finalitat, és idèntica a la caixa, sense que tingui cap especificació concreta. ${ }^{21} \mathrm{~A}$ totes les cases trobarem moltes caixes i força taüts.

Les caixes petites serveixen normalment per a guardar objectes petits i preuats. Poques vegades estan a la vista, ja que és habitual trobar-les desades dins de les caixes grans. Són els «caxenus» (que pròpiament, com ho veurem tot seguit, són partions d'una caixa gran) i les «caxiuncula», que en el català parlat són caxietes -a vegades encara «caxieta parva»- o estoigs. També podem trobar algunes «capsas» - "capsies» o «pixides», en llatí-, que és el tipus més petit de caixeta.

El més habitual és que les caixetes siguin de fusta, que si és pintada adquireix més vàlua, però les millors caixetes són fetes d'os, i algunes, sempre escasses, encara són més valorades perquè són d'ivori. L'estoig, per la seva part, solem trobar-lo o de fusta o de cuir.

L'interior d'una caixeta o d'un estoig sempre guarda un objecte preuat. Jaume Forn tenia una "caxietam modicam de osse" per a desar-hi un ganivet de plata, $\mathrm{i}$ Jaume Cànoves feia servir la caixa d'os per a guardar-hi roba fina treballada amb seda i plata, mentre que Pere Olms serva els seus anells en una «capsia cum clausura». ${ }^{22}$ Les joies i els objectes de plata sempre els trobem dins de caixetes, capses o estoigs, encara que també hi trobarem guants, cordons de seda per a segellar 0 altres petits objectes, normalment importants, poques vegades hi trobem foteses a l'interior d'una caixeta. No és estrany, doncs, que moltes caixetes portin tanca amb clau, si bé a efectes de seguretat no se'n refiaven gaire, de la tanca, perquè, com ho demostra a la pràctica el notari Pere de Colomer, «un caxenus cum clausuram» es pot «aperiri feci sine clave». ${ }^{23}$

Les caixes són idònies per a fer separació d'objectes semblants. Així, una persona que ha de tenir monedes diferents, com el mercader Jaume Cànoves que

18 ACB, llibre notarial 9, fol. 13 r., per exemple.

19 La caixa de Maria, la difunta esposa de Guillem Pere d'Esplugues, reuneix totes aquestes característiques (ACB, pergamí 1-7-2551).

$20 \mathrm{Cal}$ adonar-se que «atahut» és, en els textos estudiats, un mot de gènere femení, com caixa o arca, i no pas masculi com és actualment.

21 Podem veure com s'aproximen els termes «caixaw i «taùtw a $\Lambda C B$, llibre notarial 9, fols. 12 v. $i$ ss.

22 ACB, pergami 4-10-58a, llibre notarial 9, fol. $13 \mathrm{v}$. i pergami 1-7-3014 respectivament.

23 ACB, pergami 1-7-3014. 
necessita tenir diferents monedes segons a on mercadeja, ${ }^{24}$ utilitza caixes per a tenir les monedes separades $i$ no barrejar-les. ${ }^{2 s}$

Pel que fa a l'estoig, cal dir que sol ser un recipient més adaptat al seu contingut que no pas les caixes. Per això, l'esmentat Jaume Cànoves té un estoig per a guardar unes balancetes amb els seus pesos $\mathrm{i}$ en té tres més de cuir expressament «abtos ad ciphos argentos conservandon. ${ }^{26}$ És molt habitual usar estoig de cuir per a guardar les copes de plata. Es tracta d'uns estoigs expressos que trobem a la majoria de les cases que tenen copes de plata, i per això els veiem així esmentats encara que no duguin a dins els objectes que se'ls destinen: «unum conservatorium de corio ad opus ciphi argentin."

El concepte d'ordre a partir del qual s'endrecen els objectes en les caixes es basa en la utilitat i la freqüència d'ús. Aquest concepte d'ordre ha passat desapercebut a alguns investigadors que s'hi han apropat i han pensat que dins de les caixes tot era desordre i confusió, tal i com pot semblar a primera ullada, quan d'una mateixa caixa comencem a extreure peces de roba, estris de cuina, trossos de tela, caixetes... En realitat, els espais d'utilitat bàsics on endreçar les coses vénen a ser dos, la cuina i les cambres. A la cuina, hi trobem els utensilis de cuina, i sols aquests $i$ solament els trobem a la cuina. A les caixes que es guarden a les cambres hi trobem la resta d'objectes, sovint segons la matèria, però barrejant-se d'acord a la utilitat i freqüència d'ús: quan en una mateixa caixa trobem roba i estris de cuina és perquè es tracta de peces de roba que, per la seva qualitat, es guarden per a les millors ocasions i uns utensilis de cuina -com culleres i copes de plata- que de tan preuats no els hem de considerar de cuina, perquè potser mai no s'usen a la cuina, sinó objectes luxosos per a guardar. Igual hem de pensar, per exemple, quan juntament amb els objectes esmentats hi trobem les peces de l'arnès de l'amo de la casa: no és que tinguin les coses desordenades, és que aquesta barreja no fa nosa perquè, tot i l'obligació de sortir armat en cas de sentir crit de viafora, ${ }^{28}$ no era habitual haver-se de posar l'armadura.

No sols les caixes pròpiament dites guarden els objectes: cal esmentar altres mobles similars, que en realitat vénen a fer de manera molt semblant la mateixa funció. Aquí cal parlar dels arquibancs, que són una barreja de banc i de caixa gran. Són de fusta i l'interior sol estar dividit, per a facilitar-ne la utilització de l'espai, en dos o tres departaments (més sovint tres que no pas dos), cada un dels quals s'anomena també caixa.

24 ACB, llibre notarial 9, fol. 12 r. En Cànoves té turonesos d'argent, croats (barcelonesos d'argent), diners de Barcelona, besants d'or dÁlexandria, florins d'or, miries d'or, carlins d'argent (de Nàpols) i augustals d'or (de Sicília).

25 Utilitzar les capses o caixes petites com a guardiola dels diners també ho podem veure en gent que no són mercaders. Vinyoles, a l'article esmentat a la nota núm. 14 (pàg. 12) ens mostra aquesta pràctica en el cas dels estalvis d'un esmolet al final del segle XIV.

26 ACB, llibre notarial 8, fol. 13 r. i v.

27 ACB, llibre notarial 9, fol. $12 \mathrm{v}$.

$28 \Lambda$ tot arreu era obligat sortir armat en cas de sentir crit de socors, per tal de perseguir els malfactors. Encara que unes dècades posterior als anys que ens ocupen, podem veure una resposta concreta al «crit de viafora» dins de la ciutat de Barcelona a Joaquim MIRET I SANS, Sempre ban tingut béch les oques, sèrie 1", Barcelona, 1905. Pàg. 71. 
Cal apreciar que algunes caixes grans també es subdivideixen. En aquests casos podem trobar dins d'una caixa gran "caxionos ferratos». ${ }^{29}$ "Caxenus» $\mathrm{i}$ "caxions» és el nom donat a aquesta partió.

Amb molta menys freqüència que no pas les caixes s'esmenten els «cofres». El cofre solem veure'l ferrat, sobretot si és vell, i sovint pintat, amb colors com el vermell o el verd. Però pel contingut cal dir que hi trobem les mateixes coses que trobaríem en qualsevol caixa de mida mitjana o gran. No s'aprecia cap diferència en l'ús entre la caixa i el cofre, i cal deixar clar que sempre es situa el cofre en un terme molt secundari respecte a l'abundant caixa. ${ }^{30}$

I gairebé cap transcendència no tenen les arques, diferenciades de les caixes. Josep Mainar aprecia que el moble gòtic català té com a peces cabdals l'arca, el cofre i la caixa, si bé situa l'arca en evolució cap al cofre. ${ }^{31} \mathrm{Cal}$ dir que arca com a tal sols apareix molt escadusserament i amb finalitats menors: Bonanat Marí, per exemple, té una arca "apta ad tenendum farinam». ${ }^{32}$

En canvi, les «bústies» són bastant freqüents. Similars a les caixetes, no són gaire grans i solen ser molt acurades: les veurem de fusta sovint pintada i a voltes guarnides amb treball d'os, a vegades porten dues manetes d'os, o fins $i$ tot poden ser d'ivori. En alguns casos en trobem com a recipient d'espècies, com el gingebre o el clavecí, sense arribar mai a encabir-n'hi més d'una lliura (la qual cosa ens dóna una idea sobre la seva capacitat).

Un moble similar a la caixa, però més alt i amb obertura per la part frontal, és l'«armari». És un moble de fusta, apareix poquíssim, rep poca importància i s'usa ben poc: hom prefereix omplir abans les caixes. ${ }^{33}$

Algunes - poques- vegades trobarem el marfa, que és un moble amb prestatges i que veiem fix a la paret. ${ }^{34}$

Ultra aquests mobles fins aquí comentats, podem esmentar una sèrie de recipients que tenen ús a la llar. Així, trobem flascons, que veiem unes vegades d'estany, $i$ unes altres de fusta. Segons l'Alcover, que en documenta en el mateix segle XIV, hem d'entendre per flascó un "vas petit de coll estret», "per a tenir-hi líquids o pólvores", ${ }^{35}$ si bé hem d'observar que sovint es prefereix tenir-lo guardat que usar-lo, per la consideració que se li té. És relativament freqüent, en una casa ben proveïda, com és la de Bonanat Marí, en veiem quatre de fusta $\mathrm{i}$ un d'estany. ${ }^{36}$

29 En veiem diferents exemples a $\triangle \mathrm{CB}$, llibre notarial 9, fol. $133 \mathrm{v}$.

30 El contingut dels cofres contrasta amb el que constatem més d'un segle després -el 1428- a Tortosa, quan se'ns mostra el cofre com el lloc on a cada casa es guardaven els objectes més preuats (AHCT, Paeria i Vegueria I, 101 , fol 3 r.).

31 Josep MAINAR, El moble català, Barcelona, 1976, pàg. 32.

32 ACB, llibre notarial 9, fol. $133 \mathrm{v}$. v).

33 Podem veure-ho en el cas de l'armari que té Guillem Puig (ACB, llibre notarial 8, fol. 84

34 Vegeu, per exemple, el «marfanum fixum perieti» que té Jaume Cànoves (ACB, llibre notarial 9, fol. 12 v.).

35 A. M. Alcover-J. B. Moll, Diccionari català-valencià-balear, V, Palma de Mallorca, 1968, pàg. 909.

36 ACB, llibre notarial 9, fols. 133 r. i ss. 
També hem de tenir present els bacins («bassinum»), recipients sovint de llautó, i els barralets («barraletos»), recipients per a líquids que solem trobar principalment fets d'estany, encara que també $n$ 'hi ha de coure.

Ja fora dels metalls, trobem algun "tabac», que és una mena de cistellet, ${ }^{37}$ el qual, malgrat la seva finalitat domèstica evident, no solem veure entre les feines de la casa sinó sovint guardat dins d'alguna caixa. ${ }^{38}$

Més concreta, en canvi, és la finalitat de les «cires», que són de fusta i que solem trobar guardant productes alimenticis, especialment farina, per la qual cosa no és estrany veure-les a la cuina o prop de la pastera del $\mathrm{pa}^{39}$

Entre el rebost i l'obrador cal relacionar les senalles. Guillem Puig en té dues de plenes d' «una quarteria seminis spinargiorum». ${ }^{* 0}$ I també trobarem aquí les "sistelles», com la que té Pere Rovira," igual com el cabàs, les poques vegades que hi és.

Però no sortim del rebost. En un rebost ben proveït hi trobem «gerres" i "amfores». Les gerres són de terrissa i destinades preferentment a contenir oli. La seva capacitat sol ser d'una mica més d'onze quartans d'oli a cada gerra. Pel que fa a les àmfores, quan les trobem plenes sol ser de xarop. Es dedueix, pel que diuen els textos, que, d'àmfores, $n$ 'hi ha una mena de mida normal i una altra de petita - "anphoras parvas»-. Sempre que s'indica el material amb què s'ha fet l'àmfora, es diu que és de vidre (si per àmfores entenien també uns altres recipients fets amb un material diferent, cal dir que eren ben escassos: l'àmfora, repeteixo, sempre la trobem de vidre $\mathrm{i}$ segurament cal relacionar-la amb les «ampolles» de vidre que després veurem a la cuina).

Un altre tipus de receptacles són els sacs. No s'usen per a encabir objectes de la casa. Els trobarem a la botiga, plens d'espècies (clavecí, pebre, laca, indi o gala principalment) o cotó sobretot, si bé això dependrà de l'ofici de l'amo de la casa. També els podem trobar al rebost, plens principalment d'ordi o de farina (sovint farina de forment, encara que també en veiem d'ordi).

El nom de sac és un nom genèric que ens pot portar a confusions. És sac tant si es tracta d'un receptacle de gran cabuda (fins a catorze roves de pebre, per exemple) com si és una bossa on guardar-hi els papers - «instruments»-dels negocis o un saquet on posar-hi monedes, com els dos sacs amb monedes turoneses que té en Cànoves dins d'una caixa. En canvi, quan trobem «saca», en femení, es refereix sempre a un receptacle de gran capacitat, arribant a contenir al voltant de tretze

37 Els inventaris ens indiquen la seva presència, no gaire constant, però no ens el descriuen. Segons Joan Coromines (Joan COROMINES, Diccionari etimològic i complementari de la llengua catalana, VIII, Barcelona, 1988, pàgs. 173-174) es tracta d'una «paneretan, i el Diccionari catalia-valencià-balear (ob. cit., X, 1969, pàg. 92) ens diu que era una «cistelleta rodona més ample que alta per a tenir-hi pa, fusta, flors, objectes de treball d'agulla de les donesn. $3014)$.

38 Domènec Olms, per exemple, té un tabac dins d'una caixa pisanesca (ACB, pergamí 1-7-

39 ACB, llibre notarial 9, fols. 14 r. i 135 r., per citar dos exemples.

$40 \mathrm{ACB}$, llibre notarial 8 , fol. $84 \mathrm{v}$.

41 ACB, llibre notarial 8, fol. $57 \mathrm{v}$. 
roves de gala, per exemple, mentre que un «saquetum» és tot al contrari: sempre el veurem encabir quantitats petites (sis lliures de pebre, per exemple). ${ }^{42}$

Els sacs solen ésser fets amb matèries dures i grolleres. Principalment els trobem de xarpellera (teixit ordit a partir de l'estopa, que és el filament rebutjat després de treballar, en aquest cas, el lli). I també en trobem de canemàs (teixits amb l'estopa del cànem), sobretot els saquets. Cal constatar que les saques no les veiem de «sarpeyeria».

A vegades també constatarem la xarpellera individualitzada, com a teixit groller que, sense haver de tenir concretament la forma de sac, serveix per a embolicar coses o transportar-les. ${ }^{43}$

Un altre recipient és l'esporta. És una mena de senalla que té tanta cabuda com el sac o més (hi trobem, per exemple, fins a més de divuit roves de canyella, producte que sempre veiem viatjant dins d'esportes).

Cal esmentar encara les bosses. Són les «marsupia» i les «bursae». Es diferencien dels sacs en la seva capacitat menor i en la seva matèria primera: són de seda i, alguna vegada, de cuir. Sovint estan treballades i enguarnides per tal de fer goig, com les dues que deixa en morir Domènec d'Olms. ${ }^{44}$ Aquestes bosses es poden ajustar amb la corretja a la cintura i així lluir-les al carrer, fent la funció de les butxaques. Sol combinar-se la corretja amb la bossa i un ganivet, en el millor dels casos, amb el mànec d'ivori. Així, no és estrany trobar una «corrigia operata de cirico cum quodam marsupio de cirico et cum quodam ganiveto cum manubrio de ebore cum vagina de camut", "s o una "corrigia de corio virmilio cum marsupio de corio alboet cum uno ganiveto cum manubrio de ebore». ${ }^{46}$

\section{Robes $i$ complements per al cos}

Un cop coneguts els mobles i els recipients, cal que els obrim i comencem a treure'n objectes. La primera impressió que podem tenir en fer això és que les robes, les teles en general, són moltes.

Efectivament, la roba per a vestir, "factam ad usum et servicium corporis mei», en paraules de Geralda de Puig, ${ }^{47}$ i la necessària per a les activitats de la llar és numèricament allò que més es troba.

Comencem per la roba de vestir. Es tracta d'un element molt important. Carmen Bernís planteja que al segle XIII, amb l'increment de la vida urbana, el vestit augmenta la seva funció de diferenciació social, i aquesta seria la principal causa de

42 Podem anar veient tot això en llegir i comparar, per exemple, els inventaris de Jaume de Puig i de Jaume de Cànoves (ACB, llibre notarial 8, fols. 84 v. -86 r. i llibre notarial 9, fols. 12 r.- 16 r.).

43 Ho veiem per exemple a l'obrador del capeller Pere Rovira (ACB, llibre notarial 8, fol. 57 v.).

44 ACB, pergamí 1-7-3014.

45 ACB, llibre notarial 9, fol. $13 \mathrm{r}$.

46 ACB, llibre notarial 8, fol. $58 \mathrm{r}$.

47 ACB, llibre notarial 8, fol. 84 v. 
la gran diversitat de peces i models existents. ${ }^{48}$ Si tractem d'agrupar les moltes robes que trobem, coincidirem amb la mateixa autora en una certa divisió tripartita: «un traje de debajo que podría llevarse a cuerpo, un traje de encima y un sobretodon. 49

Començant, doncs, per les peces de sota, esmentarem en primer lloc la presència de les trabugueres que, com ho dedueix l'Alcover per a la Baixa Edat Mitjana, "llavors es durien al capdamunt de les cuixes». Solen anar òbviament aparellades $\mathrm{i}$ les trobem de seda, sovint de color «livido».

Podem ben bé entendre les trabugueres com a lligacames que subjecten els "cayrells» o "quadrells». Els quadrells, seguint també la definició de l'Alcover, podem veure'ls col.locats "des del turmell fins al ventre de la cama»." Els qui tenen quadrells -no a totes les cases hi ha trabugueres i quadrells, si bé on trobem una cosa normalment també veiem l'altra- acostumen a tenir-ne molts, i els guarden dins d'una caixa expressa. Així, per citar un exemple, Jaume de Forn tenia dins d'un taüt "unam caixam plenam de quadrellis»."

Algunes vegades trobarem el "farcetum», que era una mena de samarreta molt cenyida. Cànoves en tenia una "de sindone virmilia»." I també algunes vegades veurem camises, normalment per a l'home, i sovint "cum corda de sirico", encara que també $n$ 'hi ha de fil d'estopa, la matèria més barata. ${ }^{54} \mathrm{~L}$ 'equivalent en la dona és el brisall, que, a l'igual de les camises, trobarem en poques ocasions. Sobre la matèria primera del brisall podem dir que, en morir en Cànoves, es va inventariar a casa seva una tela de seda d'Alexandria "ad opus brisaldi»."

A sobre d'aquesta roba que podem anomenar interior, hi va la túnica, que cobria tot el cos i part de les cames. Una ullada a les túniques de les quals ens arriba referència, ens indica que la majoria són de tela de color blanc - «panno albo»- o de color pàl.lid cru - "panno livido»-, si bé també se n'inventarien de verdes o de més d'un color ( «mextadada»). Com que no és sempre la peça de vestir més externa, sols la trobem amb caire especialment luxós en pocs casos, i fins $i$ tot entre la gent molt rica només algunes vegades trobarem túniques especialment luxoses: Bonanat Marí en té algunes de fetes amb teles de Malines, ${ }^{36}$ i Pere Rovira encara va més enllà, té una túnica de color pàl.lid decorada amb trenta-sis botons de plata."

Un tipus de túnica és la cota, tal i com ho indica Bernís. ${ }^{58}$ Cal dir, però, que la

48 Carmen Bernís Madrazo, Indumentaria medieval española, Madrid, 1956. Pàg. 19.

49 Ibidem.

50 A. M. Alcover - F. B. Moll, Diccionari català-valencià-balear, X, Palma de Mallorca, 1969, pàg. 541 .

51 A. M. Alcover - F. B. MOLL, Diccionari català-valencià-balear, IX, Palma de Mallorca, 1969, pàg. 53.

$52 \mathrm{ACB}$, pergamí 4-10-58 a.

53 ACB, llibre notarial 9, fol. 13 v.

54 Vegeu-ho per exemple a ACB, llibre notarial 9, fols. 133 r. i ss.

s5 ACB, llibre notarial 9, fol. 12 v.

56 ACB, llibre notarial 9, fol. $134 \mathrm{r}$.

57 ACB, llibre notarial 8, fol. 57 v.

58 Carmen BERNís, ob. citada, pàg. 21. 
cota, així diferenciada, no apareix gaire. Podem definir la cota amb les paraules de l'Alcover: "vestit que portaven els homes i les dones i que arribava des del coll fins a prop dels peus". ${ }^{99}$ Sovint sobre la cota no es portava cap altra roba, i per aquesta raó habitualment la veurem amb trets luxosos. La podem trobar amb llenques de pell de conill ${ }^{60}$ i moltes vegades es complementa amb un caperó a manera de caputxa, que pot ser "coloris de fetge», com la que tenia Domènec Olms. ${ }^{61}$

La peça especialment ideada per a cobrir la túnica és, evidentment, la sobretúnica. Aquesta és una roba que es llueix al carrer i per això és sempre molt luxosa. Una bona sobretúnica ha de combinar la tela i les pells. La pell hi és present amb llenques que sempre solen ser de pell de conill $i$ que en els millors casos veiem escollides en un color uniforme blanc o negre. La part de roba acostuma a ser de color vermell, verd, ensafranat o morat, i sabem que a vegades és tela "de bifa marbrina», -tela lleugera $i$ força apreciada, sembla que d'origen francès ${ }^{62}-$, mentre que unes altres incorpora part de «sindone» -que és el nom que rebia una bona tela de lli $i$, segons Niermeyer, també de seda ${ }^{63}$ - . En els millors casos, el luxe encara es reforça amb la presència de botons de plata, com la sobretúnica de l'esmentat Rovira, que és «de panno livido cum penna nigra cirogrillorum cum duabus duodenis botonorum argenti». ${ }^{64} \mathrm{Cal}$ dir, però, que aquest recurs, a l'igual del de posar botons luxosos a la túnica, és ben escàs, fins i tot entre la gent molt rica. I pel que fa als tipus de sobretúnica, sabem que unes eren escotades, mentre que la majoria no ho eren, $i$ algunes fins $i$ tot tenen caputxa.

Pràcticament identificat amb la sobretúnica trobem les «epitogeria», ${ }^{69}$ que veiem de colors morats, violacis o barrejats, amb tela de síndona moltes vegades. Es diferencia entre un model femení i un model per a baró. És l'única roba on trobem que s'hi apliqui, per a guarnir, orfret, com ho veurem més endavant en parlar de les joies. ${ }^{66}$

Cal aquí també considerar la «clàmide». N'hi ha de «llistades», per la distribu-

59 A. M. AlCOVER - F. B. MOLl, Diccionari català-valencià-balear, III, Palma de Mallorca, 1968, pàg. 666.

$60 \mathrm{Cal}$ tenir present, per tal d'entendre la importància i el luxe que suposava la pell de conill, que és precisament a la Baixa Edat Mitjana quan comença a domesticar-se el conill, i encara al segle XVI predominarà més el caçat que no pas el domesticat (Robert DELORT, Les animaux en Occident du Xe au XVIe siècle. "Actes du XVème Congrès de la Société des Historiens Mediévistes de lÉnseignement Supérieur Public», (Université de Toulouse-Le Mirail, 1985). Pàgs. 33-37).

$61 \mathrm{ACB}$, pergamí, 1-7-3014.

62 Aquest origen francès el dedueix IÁlcover-Moll per a la Baixa Edat Mitjana des d'un punt de vista lèxic. (Vide supra referència d'aquest diccionari). Sobre l'origen del mot, però, també podríem tenir en compte que «bifa» ens parlés de «dues maneres» de tela, sobretot a partir de les accepcions de "bifariam» i «bifarie» que trobem a CASAS HOMS, Glossari llati-català medieval, «Miscelánea filológica dedicada a Mons. A. Griera», (Instituto M. Cervantes-Instituto de Estudios Pirenaicos, CSIC, 1955). Pàg. 150.

63 NIERMEYER, Mediae latinitatis lexicon Minus, Leiden, 1976, pàg. 973.

64 ACB, llibre notarial 8, fol. 57 v.

65 "un vetêment porté pardessus la toge», segons Niermeyer, ob. citada, pàg. 378.

66 ACB, llibre notarial 9, fols. 128-132, veiem els diferents tipus d' «epitogerian que apareixen a casa de Bonanat Marí; i a 134 r. apreciem l'esmentada decoració. 
ció dels colors, unes altres són de color porpra, i algunes tenen llenques de pell, que serà de conill o fins $\mathrm{i}$ tot més preuada - «vayre»-. Totes són ben luxoses, no sols les que empren la pell: la roba llistada també podia denotar luxe, i per això, en aparèixer les ordinacions contra el luxe a Barcelona, serà vedat a les dones vestir «de drap listat ne scacat" ${ }^{67}$. La clàmide sovint ha estat identificada amb un mantell curt, ${ }^{68}$ si bé això pot contrastar amb els tipus coneguts de "clàmide», especialment la "saya», que sol ser precisament una vestidura llarga. I un altre tipus força corrent és l' "alemandesc», dit així perquè imitava un model d'origen alemany. Aquesta varietat permet realitzar una sèrie de combinacions, com ho veiem en Domènec d'Olms, que té "quandam clamidem de saya tinta in grana cum pena vayre». ${ }^{69}$

Per a subjectar la clàmide el més idoni són els afiblalls i els teixells. Els afiblalls hem d'imaginar-los com una sivella amb dues peces, una a cada banda de la clàmide, per això sempre es sol esmentar en plural. Hi ha dos tipus d'afiblalls. El més escàs és el que, per la seva forma arrodonida i allargada, és anomenat de canons, mentre que els afiblalls més corrents tenen una forma menys allargada. Per la seva vistositat externa, els afiblalls es converteixen facilment en peces de guarnir. Així, els de canons solem trobar-los de plata, $\mathrm{i}$ acostumen a relacionar-se amb clàmides femenines, com els que Bernard Faylibe regala a la seva filla. ${ }^{70}$ Els que no són de canons no solen ser tan luxosos, i els trobarem normalment de seda, si bé la seda es pot complementar amb botons o amb perles, com els que té Bonanat Marí. "Els afiblalls de seda els trobem sovint de color violaci a les clàmides femenines $\mathrm{i}$ de color vermell quan són "aptos ad clamidem hominis»."

El teixell, per la seva part, és cada una de les dues peces que es col.loquen també a la clàmide - per això es sol parlar de «parell de teixells»-, amb la mateixa funció que els afiblalls, els quals substitueixen. Els teixells són quadrats -com els daus, d'on els ve el nom- $i$, com a característica bàsica, solen dur alguna pedra preciosa o perles. Per aquesta raó el seu preu sol ser elevat: Sibília, esposa del pintor Berenguer Ermengol, per exemple, paga 7 lliures i 14 sous per «uno pari taxillorum in quibus erant incastate sive enfilate tres uncie minus medio argencio perlarum veritum, minutarum et viridarum". ${ }^{73}$ Algunes vegades trobarem els teixells marcats amb el «signum» del seu propietari, com ho fa fer Bonanat Marí, tant en els seus teixells de plata com en els de perles. ${ }^{74}$

Parlant de peces especialment guarnides, podem esmentar, tot i que apareixen molt poc, els «orals». Són uns mocadors de coll que acostumen a ser força luxosos, sovint posant-hi perles, com el que té Maria Esplugues. ${ }^{75}$

67 IMHB Arxiu del Batlle i del Veguer de Barcelona, X-1 Fol. 5 v. - 6 r.

68 Així ho veiem, per exemple, a Carme BATLLE, La familia i la casa d'un draper de Barcelona, Burget de Banyeres (primera meitat del segle XIII), «Acta Mediaevalian, II (1981), pàg. 85.

$69 \mathrm{ACB}$, pergamí 1-7-3014.

$70 \mathrm{ACB}$, pergami $1-7-2551$.

71 ACB, llibre notarial 8, fol. 132 bis v.

72 ACB, llibre notarial 9, fol. 13 v.

$73 \mathrm{ACB}$, pergamí 1-7-3014.

74 ACB, llibre notarial 9, fol. 132 bis v.

$75 \mathrm{ACB}$, pergamí 1-7-2551. 
Ens queda encara parlar de les gramalles. De gramalles no en trobem a tot arreu. Sols les solem veure entre els que tenen poder municipal: les trobarem a les cases de Jaume Cànoves i de Pere Rovira, que sabem que foren membres del Consell de Cent, i també en té Bonanat Marí, membre d'una família igualment lligada al govern municipal. ${ }^{76}$ En aquests personatges s'ajunta una elevada posició sòcio-econòmica amb la participació en el poder municipal. Com correspon, la gramalla sempre és luxosa i lluïda. Sol portar llenques de pells, tant de conills - «cirogrillorum»-com d'altres animals més preuats encara - «vayres»-, i de tela a vegades s'hi posa «sindone». En el color de la tela predomina el color pàl.lid, o el vermellós de la síndona, i a vegades combina colors («mesclat»). En moltes ocasions porta incorporada caputxa. Un altre tipus de gramalla combina la tela amb el "camallet», que hem d'entendre com un teixit de llana mesclat amb pèl de cabra. També la podem trobar combinant les pells amb tela de Malines, o fins $\mathrm{i}$ tot enguarnida amb plata o botons de corall, si bé cal dir que aquest luxe és molt poc emprat. ${ }^{77}$

Molt escadusserament trobem el rodondell, que era un tipus de capa de forma quasi rodona, $\mathrm{i}$ que segons Bernís és una innovació del segle XIII. ${ }^{78}$

En aquest mateix grup de robes, cal encabir-hi els «alquinces» o alquicers, que hem d'entendre com una capa que també es podia emprar per a cobrir-se al llit, i a la qual es pot suposar un origen en teles musulmanes. Els que coneixem són blancs $i$ llistats alhora. Per raó de les teles diferents que pot portar, aquesta roba era també coneguda com «barregada».

I pel que fa a les capes, les trobem preferentment o de bifa marbrina o d'estam (fil de llana). L'estam el solem trobar vermell, mentre que les capes de bifa marbrina les veiem de color verd, que és el color més corrent en aquest tipus de tela. Però també existeixen capes especialment guarnides amb trossos de síndone vermella $o$ amb llenques de pell de conill, com les que té Bonanat Marí. ${ }^{79}$

Respecte als complements de la roba, caldrà esmentar les corretges, inventariades a vegades com a «cintes». Les més senzilles són de llana sense guarniment, però les més corrents són de seda $i$, encara que a vegades no porten guarniment i les podem trobar merament descrites pel seu color blanc, és molt normal que siguin treballades per a fer goig. Sovint és la mateixa seda la que s'ofereix especialment treballada, però un refinament relativament habitual és recobrir la corretja amb peces d'argent, que queda aleshores «munita de argento». L'amplada de la corretja varia segons els casos, normalment trobem que les guarnides d'argent són estretes.

Aquestes corretges ajusten la roba a manera de cinturó, i a més serveixen per a sostenir i portar la bossa i si s'escau un ganivet, com ja ho he indicat abans, en parlar de les bosses. Algunes vegades, poques, la corretja és de cuir, i compleix les mateixes

76 Coneixem aquesta situació tot resseguint Joan Francesc BOSCA. Memorial Històric, edició a cura de Jaume SOBREQUÉS I CAllicó, Barcelona, 1977.

77 De totes les gramalles vistes sols trobem especialment luxoses, amb treball de plata i corall, les de Pere Rovira (ACB, llibre notarial 8, fol. 57 r i v).

78 Carmen BerNís, ob. citada, pàg. 22.

79 ACB, llibre notarial 9, fols. 132 bis v. -133 r. 
finalitats, però feta tota en cuir, fins i tot la bossa, com en el cas ja vist de la corretja de Guillem Puig que és "de corio virmilio cum marsupio de corio albo». ${ }^{80}$ En aquests casos en què la corretja és de cuir, porta una sivella anomenada virolla que es destaca especialment, i per això la podem trobar de plata.

Pel que fa a sivelles, no n'apareixen gaires, però quan apareixen són de metall: llevat de les esmentades virolles de plata, la majoria solen ser de llautó o de coure.

Un altre tipus de complement molt usual són els barrets. Són molt corrents i no és estrany tenir-ne bastants. És habitual que siguin de seda, però també n'hi ha de lli.

El barret que trobarem més concretat és el "galerum» o «capell de sol», ${ }^{81}$ potser de palla, i amb una corda que es passa pel coll i que sol ser de seda, encara que algunes vegades és de llana. El trobarem moltíssim, i que era molt utilitzat ho podem confirmar si entrem a l'obrador d'un capeller: el que més hi veiem són capells de sol. ${ }^{82}$ S'emprava per a cobrir-se el cap durant els viatges. Precisament en alguns indrets com Reus, les ordinacions municipals indicaran als messeguers que estiguin a l'aguait perquè hi ha gent que, al llarg del camí, pren la fruita dels camps i l'amaga en el "capell de sol»."

És clar que també s'especifiquen uns altres models de barrets, com els capells francesos («francisci»), i a casa de l'esmentat capeller podem augmentar-ne la tipologia: en podem trobar d'alemanys, camellins, sicilians o de sol castellans. ${ }^{84}$

La seda també la veurem a les albaneques, que serveixen per a recollir el cabell femení, i no n’apareixen gaires. I cal també tenir present les sàvenes, que són mocadors de cap. Solen ser de seda, però també en trobem de lli. Ens n'apareix el tipus corrent $\mathrm{i}$ un altre d'anomenat "savenna sarracenica», ${ }^{85}$ que hem de suposar inspirat en teles musulmanes.

I tampoc no podem oblidar els guants -els «cirotheca»-. No n'apareixen gaires, com a molt un o dos parells a les cases riques. N'hi ha de dos tipus. Uns són de cuir, com els que té Cànoves, que són de pell de cèrvol. I els altres, els que no són de pell, s'anomenen guants "plans», sens dubte perquè no essent de cuir no queden bufats en treure'n la mà.

Ens apareix també, és clar, el calçat, però tan poc que fa pensar que pràcticament sols devien disposar del que portaven posat i poc més. Sovint en tenim pocs detalls - «calcearium» i prou-. Però algunes vegades l'inventari n'especifica una mica més. Aleshores trobem tant parells d'espardenyes ${ }^{86}$ com, una mica més freqüents, esclops. ${ }^{87}$ També trobem «caligas», ${ }^{88}$ sobre les quals, tot i que les explica-

80 ACB, llibre notarial 8 , fol. $58 \mathrm{r}$.

81 "Galerum sive capell de sol" ( $\mathrm{ACB}$, llibre notarial 9, fol. 13 v.).

82 ACB, llibre notarial 8 , fols. 57 r. i ss.

83 AHCR, Ordinacions, full sense numerar.

84 ACB, llibre notarial 8 , fol. 57 r. i ss.

85 ACB, pergamí 4-10-58 a.

$86 \Lambda C B$, pergamí 1-7-3074.

87 ACB, pergamí 4-10-58 a, per exemple.

88 Ho podem veure a $A C B$, llibre notarial 8 , fol. 57 v. 
cions coetànies no ens permeten dubtar respecte del seu ús - «descalciavit se caligas", recollim per les mateixes dades a $\mathrm{Vic}^{\text {"9 }}$-, les descripcions que se'ns ofereixen -les veiem de tela vermella- i el lloc on es desen -entre objectes luxosos- ens indiquen que el mot, en part, es va buidant del seu sentit originari i segurament cal imaginar-les com unes calces llargues.

\section{Robes i teles per a la llar}

De mica en mica, o de peça en peça, hem anat introduint-nos en les peces de roba. Cal que observem, abans de continuar analitzant la resta de teles $i$ robes que surten de les moltes caixes, que no sols s'usava molta roba sinó que les peces es solien confeccionar a casa. Això explica que ens trobem trossos de roba a totes les cases, especificant-ne la llargada en pams i canes.

El que més trobarem són teles de lli, i en segon lloc en veurem de seda. Les altres teles ens apareixen ja amb molta menys freqüència.

La síndona -que ja he dit que s'obtenia del lli o de la seda- la trobarem sempre en colors ensafranats i vermellosos pujats. I també hi podem veure estam (fet a partir de la llana, com ja he indicat), sovint de color vermellós, i trossos de fustany (teixit fruit de combinar el lli amb la llana o amb el cotó). Respecte al fustany, potser és adient de recordar que vivia un moment d'auge i el 1309 va haver de ser regulada pel consell municipal la seva composició. ${ }^{\circ}$

No falten, evidentment, les teles d'estopa (el filament de rebuig de treballar el lli principalment, com ja ho he indicat), a vegades «llistades» amb diferents colors.

Sovint, però, no sols és la roba sinó també la mateixa tela la que es fa a casa. Per això, posem com a exemple, trobem a la casa de Jaume Forn una caixa plena de lli dÁlexandria ("usque ad mediam rovam») i un arquibanc de tres caixes amb un d'aquests departaments ple de lli corrent, "usque ad unum quartonum»." En algunes cases arribem a trobar els estris necessaris per a portar a terme tot el procés de fabricació del lli, amb la post $\mathrm{i}$ les pues de ferro necessàries per a pentinar el lli $\mathrm{i}$, ben a prop, els "ramos filati lini crudi»" ${ }^{92}$ ol lli pentinat. ${ }^{93}$

Entre la roba ja confeccionada, podem començar apreciant la presència de les tovalloles, que en trobarem moltes, en colors blancs o llistats, i fetes de lli o d'estopa. Malgrat que l'estopa és pitjor considerada que el lli, en totes les cases n'hi ha de tots dos materials: a casa de Bonanat Marí, que és força ric, en comptem sis de lli i nou d'estopa, per citar un exemple. ${ }^{94}$ Algunes vegades -molt poques- afegeixen al lli fil de cotó. En canvi, és molt corrent posar-hi seda. Mai no veiem tota una tovallola de seda: a vegades porta una folradura de seda ( «cabada de cirico» ${ }^{95}$ ) i unes altres

89 AVV. Processos criminals, lligall 2 (1300), plec 3, full sense numerar.

90 Agustí DURAN I SANPERE, Barcelona i la seva bistòria, II, Barcelona, 1972-1975, pàg. 288

91 ACB, pergamí 4-10-58 a.

92 ACB, llibre notarial, 9, fol. $14 \mathrm{r}$.

93 ACB, llibre notarial 9, fols. 133 r. i ss.

94 ACB, llibre notarial 9, fols 133 r. i ss.

95 ACB, pergamí 1-7-3014. 
mostra una part treballada amb seda, sovint els extrems («operata de sirico in eius capicibus» o "cum cirico in utroque capite" ").

Un tipus concret de tovalloles, força corrents a les cases riques, són les tovalloles "gallicas». Continuant amb l'exemple anterior, de les sis tovalloles de lli que té Marí, dues són gàl.liques. Sempre les trobem fetes de lli, la qual cosa ens indica que es caracteritzen no pas per la seva matèria primera sinó pel model seguit, un model que hem de creure d'origen francès.

Una mica més petits que la tovallola són els «tovallioni», que apareixen amb molta menys freqüència."

Similars als anteriors tenim els «manutergia», que vénen a ser els nostres draps petits o tovallons. $N$ 'hi ha molts a cada casa i sovint els trobem a la cuina. A vegades són fragments d'altres teles, però uns altres cops són peces fetes expressament, i en algunes ocasions es seguien models més preuats, com els «manutergia francisca».

A més, a la majoria de les cases trobem una o dues estovalles («mappe»), sovint a la cuina.

I amb la mateixa freqüència veurem manils («manille»). El manil té les funcions de davantal, i fins $i$ tot $n$ 'hi ha d'especialitzats: Elisenda de Puig va heretar del seu pare un "manile novum ad opus barbe», ${ }^{8}$ que hem d'imaginar-nos adaptat per a col.locar sobre el pit per tal de no tacar-se i recollir els pèls de la barba en ser retallats.

Amb una finalitat més decorativa i luxosa tenim el doblet, que solia ésser treballat amb certa delicadesa ( «dobblet levorat" ${ }^{99}$ ).

Ben diferents són els barragans, habituals a les cases de mercaders. El barragà («barraganum») era un teixit gruixut de llana, força impermeable, ideal per al transport i molt utilitzat a les naus. Tots els que trobem solen ser «llistats» amb els colors, i no tots tenen la mateixa mida.

Potser amb la neteja cal relacionar els manyocs de lli - «pilei linii»-, que trobem en una sola ocasió, en què s'especifica que són usats $i$ vells. ${ }^{100}$

També hem d'esmentar els cordons. Ens apareixen de seda (igualment, però més escadussers, de llana), i no en veiem gaires de soltś. Les seves finalitats són molt diverses. Els podem apreciar en els capell de sol, com ja ho he dit, i tanmateix són presents a les camises, a la vegada que també serveixen per al «signum» del llibre de comptes. ${ }^{101}$

Encara que escasses, trobem estores, estorins i catifes, aquestes sovint prop del llit $\mathrm{i}$ de color blanc. No en veiem a totes les cases, però a algunes llars se'n compten moltes: Bonanat Marí només té una catifa, però, en canvi, posseeix a casa seva vuit estores, totes col.locades aparellades $\mathrm{i}$ també totes del tipus d' "Alacant». ${ }^{102}$

96 ACB, llibre notarial 9, fols. 13 v. i 133 v., respectivament.

97 ACB, llibre notarial 9, 12 v., per veure'ls, com exemple, diferenciats de les tovalloles.

$98 \Lambda C B$, llibre notarial 9, fol. $12 \mathrm{v}$.

99 ACB, llibre notarial 9, fol. $12 \mathrm{v}$.

100 ACB, pergamí 1-7-3014.

101 Ibidem.

102 ACB, llibre notarial 9, fols. 132 bis - 135 v. 
Trobarem cortines, si bé pot sobtar que siguin ben poques. Les veurem gairebé sempre en l'àmbit del llit, utilitzades per a aîllar el llit de la resta de l'habitació. Les solem veure de lli de color blanc, si bé sovint es treballen per tal d'embellir-les. No hem de pensar que aquest treballat de la cortina sigui sempre amb seda, a vegades sols se'ns diu que és una "curtina alba de panno lini operata de filo». ${ }^{103}$

\section{Cobertors}

Una de les peces que més trobarem és el cobertor, el «cohopertorium». És, juntament amb els llençols, la peça que més apareix. És tracta, però, d'una paraula equívoca, perquè designa qualsevol tapa o coberta. Així, és «cohopertorium» la tapa de fusta que cobreix la pastera del pa o la tapa de qualsevol caixa o l'embolcall per a guardar el mirall. Si ens centrem en el «cohopertorium» de roba també ens trobarem en la proximitat de la confusió. Perquè s'aplica la paraula a tota tela que serveix per a cobrir qualsevol cosa: a vegades s'usa com a funda del coixí (en alguns casos amb especial luxe, com quan s'empra la pell i el pèl de boc) i també com a tapet de taula, encara que el més corrent és trobar-lo a sobre del llit, a manera de cobrellit, tot $\mathrm{i}$ disposar també de tapets $\mathrm{i}$ vànoves, com ho veurem tot seguit. La importància del cobertor és tanta que existien treballadors que no es dedicaven a altra cosa que a fer cobertors, són els «coberters». ${ }^{104}$

La matèria de què es fan els cobertors és força variada. N'hi ha de lli, de fustany i de síndona ( «de sindone regali» especifica el notari Bernat de Cumbe en un inventari ${ }^{105}$ ), però el que més apareix, fins i tot per als cobertors destinats al llit, és el cobertor fet amb bord d'Alexandria o amb bord de Barcelona. I pel que fa al color, trobem els que, a l'alçada del recorregut que fins ara hem fet, ja podem considerar com els preferits a l'època: ensafranat, vermell, vermell fort i la combinació del llistat, i també el color pàl.lid. Alguns són especialment delicats, i arriben a portar alguna tela preuada com el sendat, ${ }^{106}$ alternant amb altres teles més corrents (les llenques d'aquesta combinació són les anomenades «barres»). És el cas d'un dels cobertors de Maria, esposa del draper Guillem Pere d'Esplugues, que té «quoddam cohopertorium cum barris de panno lini albis et cum barris sendati virmili». ${ }^{107} \mathrm{I}$ un altre tipus de cobertor luxós és el realitzat amb síndona vermella i mostrant el signe personal del seu propietari. ${ }^{108}$

\section{El llit $i$ els seus guarniments}

Com ja ho he insinuat, on es destinen més peces de roba és al llit. Cal, però, que

103 ACB, llibre notarial 9, fol. $133 \mathrm{v}$.

104 APSMM, pergamins 14.010 i 14.016, veiem un tal Bernat de Vila, definit com un «coopertorarius».

105 ACB, pergami 4-10-58 .

106 Segons NIERMEYER (ob. citada, pàg. 164) hem d'entendre-ho com «un tissu de soie».

107 ACB, pergami 1-7-2551.

108 Ho veiem fer, per exemple, en el cas de Bonanat Marí, que marca diferents objectes de la seva propietat amb el seu signe (ACB, llibre notarial 9, fol. 133 r.). 
comencem per veure com són els llits. En primer lloc cal tenir una superfície plana de fusta. Poden ser barres planes de fusta, les posts. Així, podem trobar un llit fet a partir de quatre posts, ${ }^{109}$ o podem veure unes quantes posts desades on no facin nosa per a quan calgui emprar-les: Jaume de Cànoves tenia tres posts de fusta a la part de darrera de la casa -curtis- desades per a quan calgués utilitzar-les. ${ }^{110}$

Quan la superfície de fusta és més ampla, es tracta d'una taula - «tabule»-, i cada taula es fa servir per a un llit. Són els llits de taules - «lectum de tabulis»-, força habituals. A la mateixa casa de Jaume de Cànoves es guarden dotze «tabulas fustes» i onze més «tabulas aptas ad lectum».

Els esmentats són els tipus de llit més corrents. Poc corrent, en canvi, és el llit d'escó - «lectum scilicet scannum»" -, que porta incorporat un escambell per a pujar-hi, la qual cosa és ben comprensible perquè el llit podia arribar a ser ben alt. Unes altres vegades, sense arribar a ser gaire habitual, l'escambell apareix solt, independent del llit però al seu servei. ${ }^{12}$

Un llit fix consta encara d'una altra peça, el capet - «capetum»-, que és el capçal del llit. Segurament hem de pensar en la seva absència quan se'ns parla d'un «llit tornadís».

L'estructura precària que sovint té el llit explica que moltes vegades s'inventariï els complements del llit però no aquest com a moble, per la senzilla raó que com a tal no existeix.

Sobre la superfície de fusta, s'hi col.loca sempre una màrfega o sacrilet. Cada llit, sigui de la mena que sigui, té la seva «marfaga sive sacrilectum». Sempre se'ns donen pocs detalls de com és la màrfega. Maria d'Esplugues ens parla d'una "strelenca listata», ${ }^{113}$ però hem d'anar amb compte perquè tot $i$ estar al llit no tenim totes les certeses que calgui identificar-ho totalment amb la màrfega. En general devien ser tan comunes $i$ poc diferenciades que no es descriuen.

A sobre de la màrfega, s'hi col.loquen els matalassos. A vegades un llit sols té un matalàs. Sol passar en els llits dels servents, als quals, a més, s'acostuma a reservar un "matalassium ruptum veterrimum et modici valoris aptum serventi». ${ }^{114}$ Però en una situació normal el llit sol tenir dos matalassos, i altres cops tres, sense que ens hagi d'estranyar trobar-ne quatre, cinc o fins i tot set. No és rar combinar-ne un de vell $i$ un de nou. De la tela servida per a fer el matalàs i del seu color, els notaris que fan els inventaris en donen pocs detalls. Algunes vegades els troben llistats, però no se'ns ofereixen més precisions. Poques vegades van protegits amb una funda. Cànoves en té un de protegit amb una funda de cuir. ${ }^{11}$ I també sabem poc del farciment del matalàs, si bé podem apreciar, en alguns llits de les cases més riques,

109 ACB, llibre notarial 9, fol. $14 \mathrm{r}$.

110 ACB, llibre notarial 9 , fol. $13 \mathrm{v}$.

111 Ho veiem, per exemple, entre els béns de Guillem Puig (ACB, llibre notarial 8, fol. 84 v.).

112 Ja a l'Alta Edat Mitjana trobarem «scamnum» com kquae lectis altioribus adponunturn (Sant Isidor de SEvilla, Etimologias, II, Madrid, 1983, pàg. 516).

113 ACB, pergamí 1-7-2551.

$114 \mathrm{ACB}$, pergamí 1-7-2551.

115 ACB, llibre notarial 9, fol. $14 \mathrm{r}$. 
matalassos de llana, i a vegades trobem «matalafiis de metxino», que també haurem de relacionar amb la llana. ${ }^{116}$

L'estructura del llit, la màrfega i els matalassos són, per dir-ho així, la part bàsica del llit, sobre d'on s'anirà col.locant la roba necessària.

Aquí cal començar pel coixí. Era rodó i allargat, i era conegut com a «travesser». Normalment n'hi ha un per a cada llit que s'usa. Els més bons eren farcits de plomes, com el parell que en té Cànoves. "' Les mides dels travessers són bastant semblants, tot $i$ que algunes vegades se'n troben alguns més petits que els corrents. ${ }^{118}$

Especialment per al llit són els llençols. A totes les cases n'hi ha molts. N'hi ha de lli i d'estopa. Els millors presenten la vora amb puntes treballades, les randes. ${ }^{119}$ Escassíssimes vegades al lli se li afegeix alguna tela més preuada, com la «sindone violacea» que veiem en un llençol de Margarida Adarró. ${ }^{120}$ A vegades els llençols són llisos i de color blanc, però unes altres, llistats. Les mides varien (sovint s'especifica que són de quatre o de cinc pams) i a voltes també canvia el model: tenim esmentat, per exemple, «quoddam linteamen Sicilie». ${ }^{121}$ Els llençols solen aparèixer en parells, per la senzilla raó que en parar el llit se'n posen normalment dos, però fins i tot si estan guardats solen esmentar-se per parells.

En canvi, les flassades no són gaire abundoses, n'hi ha normalment una per a cada llit que es fa servir, i sovint són llistades. És més facil trobar un llit sense flassada que no pas un llit amb dues flassades. ${ }^{122}$

La majoria dels llits es queden així, tapats amb el cobertor. De les característiques $\mathrm{i}$ colors del cobertor ja $n$ 'hem parlat. Però hi ha encara dues altres peces per al llit, tot i que es troben en pocs llits. Són el tapet i la vànova. Tant l'un com l'altre hem de definir-los com a cobrellit, i cal dir que no s'exclouen, sinó tot al contrari, sovint es complementen, i per això moltes vegades trobarem ambdues peces juntes. Podem apreciar clarament com alguns notaris diferencien amb nitidesa les tres peces - cobertor, tapet, vànova-, inventariant-les amb mots diferents tot i trobar-les juntes. ${ }^{123}$ Cal repetir, però, que el més corrent és veure sol el cobertor, i entre el tapet i la vànova és més habitual trobar la vànova, el tapet apareix escassament.

Sobre les vànoves cal dir que la majoria les trobem de lli i de color blanc, i molt rarament en veurem "de metxino». ${ }^{124}$

La imatge completa d'un bon llit l'hem de fer amb una caixa al costat i amb cortina que el tanca i l'ailla de la resta de l'habitació. Ho trobarem solament en els

116 ACB, llibre notarial 9, fols. 132 bis i 134 r., com a clars exemples.

117 ACB, llibre notarial 9, fols. 12 v. - 13 r.

118 ACB, llibre notarial 9, fol. $14 \mathrm{r}$.

119 També A. M. ALCOVER- F. B. MOLL (Diccionari català-valencià-balear, IX, Palma de Mallorca, 1969, pàg. 133) documenta randes al segle XIV, si be l'estructura precisa de les randes en aquesta època no la coneixem.

120 ACB, llibre notarial 8, fol. $6 \mathrm{r}$.

121 ACB, pergami 1-7-3014.

122 ACB, pergamí 1-7-3014.

123 Un exemple clar és el que ens mostra el notari Bernat de Vilarrúbies a ACB, pergami 1-72551.

124 ACB, llibre notarial 9, fol. 134 r. 
millors llits, i en aquests casos veurem inventariada una cortina juntament amb les robes del llit, amb les característiques que ja hem comentat abans en parlar de les cortines.

\section{Coixins}

Cal parar atenció als coixins. Són un element important de les mateixes cambres de dormir, completant el llit. Ja hem parlat del coixí allargat, el travesser. De coixins, n'hi ha molts més. En el mateix llit podem trobar la «culcitra». És un tipus no gaire freqüent, quan el veiem sempre és al llit, $i$ acostuma a ser força bo, en el millor dels casos de plomes. També propi del dormitori és el "pulvinar», ${ }^{129}$ que apareix encara menys que l'anterior $i$ que no els hem de confondre pas, perquè podem veure notaris com Bernat de Cumbes que els distingeixen amb nitidesa. ${ }^{126}$ També al llit trobarem els «capcialia», que podem imaginar usats per a recolzar-hi el cap, i que es col.locaven al capçal del llit, sobre el travesser, normalment un parell, altres vegades tres. ${ }^{127} \mathrm{~A}$ diferència dels anteriors, aquest coixí és molt corrent, gairebé imprescindible, almenys en els millors llits de la casa.

Un altre tipus de coixí és l'auricular - «auriculare»-. El nom fa referència a la utilitat de recolzar-hi l'orella. Acostumen a ser ben guarnits, i per això mateix sovint els trobem guardats en caixes. Els millors són treballats en seda, com el que té Jaume de Forn, que és «operatum ex ambabus partibus operibus siricis cum flochs de siricon. ${ }^{12 x}$

Unes altres vegades, se'ns parla lacònicament de coixins - «cuxinos»-. A totes les cases en veiem. No els trobem sobre els bancs o escons sinó normalment en caixes o en l'àmbit del dormitori. La majoria presenten treballs de seda en una o dues parts del coixí, i alguns són de plomes. Els més senzills són fets a partir d'una tela de lli, que sovint trobem de color blanc, i els més bons els solem veure de síndona, amb el característic color vermellós. Els treballs de seda es conjuminen, en els millors casos, amb la tela del coixí, i podem trobar, per exemple, coixins «de scindone virmilia cum aliquibus operibus de cirico croceon. ${ }^{129}$

\section{Taules $i$ seients}

Ultra el llit i les caixes que comentàvem abans, hem d'imaginar-nos pocs mobles a la casa. El que més hi trobarem són taules. Com a mínim n'hi sol haver una a cada casa. N'hi ha de totes mides - «magna», "parva»-i pel que fa a la forma predominen les allargades, tot $i$ que també en trobem de rodones. La majoria de les

125 A l'Alta Edat Mitjana ens l'esmenta Sant Isidor de Sevilla com un coixí que forma part dels complements del llit (Isidoro de Scvilla, Etimologias, II, Madrid, 1983, pàg. 516).

126 ACB, pergamí 4-10-58a.

127 Vegeu per exemple la pintura reproduïda a la pàgina 14 de la Enciclopedia Salvat de la Decoración, I, Pamplona-Barcelona, 1982.

128 ACB, pergamí 4-10-58a.

$129 A C B$, pergamí 4-10-58 a. 
rodones són taules petites. ${ }^{|x|}$ Existeixen taules fixes (amb les potes subjectades més o menys perpendicularment a una superfície plana de fusta) $i$ unes altres de plegables - "plicabilem»-. Per a aquestes existeixen uns peus de fusta - "pedes fusteos tabule»que es col.locaran per tal de sostenir la superfície plana de fusta - "tabula de postibus»-. Sovint en inventariar una «tabula» es dirà si és «cum pedibus» o sense.

Si bé la taula plegable ens ofereix la correcta idea de la provisionalitat i la necessitat d'aprofitar al màxim i de manera polivalent l'espai de la casa, cal que no desconeguem que hi ha taules plegables luxosament treballades, encara que molt poques: Bonanat Marí tenia una «mensam plicabilem cum quibusdam operibus sculpturis". ${ }^{31}$

Totes les taules són fetes de fusta, i sempre que se'ns indica el tipus de fusta se'ns diu que és de noguer.

Per a seure hi ha, en primer lloc, els bancs, que es col.loquen al costat de la taula en el moment de menjar. ${ }^{132} \mathrm{Si}$ el banc té respatller es tracta d'un escó. I un altre tipus de banc per a seure ja l'hem comentat abans: l'arquibanc, que serveix de banc i de caixa on es guarden separadament les coses.

A l'àmbit de la cuina trobem bancs, arquibancs, escons i cadires, de les quals parlarem tot seguit. És clar, però, que no hem d'imaginar-nos que sols s'asseien per menjar. És relativament freqüent trobar seients al dormitori, on sovint veurem un o dos "seti» o "sedilia». " És interessant poder constatar que els millors d'aquests seients són de color: Maria d'Esplugues té al seu dormitori «duo sedilia de colore nigro et croceo" (negre i ensafranat). ${ }^{134}$ Sovint veiem els setis recoberts amb una tela, que principalment és "de panno croceo e virmilio". ${ }^{135}$

Unes altres vegades s'inventaria una "catedra sive sedens». Hem d'entendre-ho també com una cadira, sempre de fusta, i l'hem de situar al dormitori o a la cuina. ${ }^{136}$

Mainar insisteix en no confondre els setis amb la cadira, precisant la superioritat d'aquesta. ${ }^{137}$ En els inventaris, efectivament, es diferencien bé, amb predomi dels setis.

A les bones cambres de dormir podem trobar els «seti» o «sedilia» acompanyats d'un escó - «scannum»" ${ }^{13 *}$. Aquest objecte no l'hem de confondre amb l'escó de la cuina. És l'escambell, que ja hem vist en parlar del llit, i que té la finalitat de facilitar-hi l'accés.

130 ACB, llibre notarial 9, fol. 14 r. com a bon exemple.

131 ACB, llibre notarial 9, fol. $133 \mathrm{v}$.

132 Francesc Eiximenis escriurà, unes quantes dècades després, que els catalans es distingeixen d'altres pobles en el menjar, entre d'altres raons perquè «mengen seent en taula» (Francesc EIXIMENIS, Terf del Crestià, cap. CCCLXXII; a Lo Crestià, Barcelona, 1983, pàg. 148).

133 Vegeu, per exemple, ACB, pergami 1-7-2551, i el llibre notarial 9 fols. 13 r.- 14v., com a exemples significatius.

134 ACB, pergamí 1-7-2551.

135 Ho podem veure, per exemple, a ACB, llibre notarial 9, fol 13 r.

136 ACB, llibre notarial 9, fol 14 r., per exemple, on podem apreciar ambdues ubicacions.

137 Josep MAINAR, El moble català, Barcelona, 1976, pàg. 52.

138 ACB, llibre notarial 9, fol. 14 r., per exemple. 
Cal dir que les cadires es conserven encara que s'hagin quedat sense seient, i tot sembla indicar que es deuen reparar tant col.locant-hi fusta com potser afegint-hi cuir, a la manera dels recolzadors de cuir. ${ }^{139}$

Amb la mateixa finalitat de seient trobarem fins i tot la paraula "sella», distingint aleshores entre "sela aptam ad sedendum» $\mathrm{i}$ "sellis equo». ${ }^{140}$

Podem també aquí fer esment dels recolzadors o "recoudedors» de cuir. Eren molt freqüents, pràcticament en trobem bastants a totes les cases. Són, efectivament, de cuir, a vegades s'inventaria el cuir adquirit expressament per a convertir-lo en recolzadors. ${ }^{141}$ Alguns els trobem en diferents llocs de la casa, uns altres apareixen guardats, $\mathrm{i}$ això fa pensar que almenys no tots eren d'ús diari o constant. I tot sembla indicar que cal imaginar-los com un suport o coixí de cuir.

\section{Cuina, rebost $i$ els seus complements}

Ens cal encara entrar en un àmbit ben concret: la cuina. Els estris que trobarem a la cuina són escassos però significatius perquè ens indiquen què fa falta per a cuinar segons l'alimentació del començament del segle XIV. ${ }^{142}$

Per a cuinar trobarem graelles, paelles, calderes i asters. Quan s'especifica la seva composició, la graella la trobem de ferro, les paelles de ferro o de coure, amb preferència per l'aram, i les calderes de coure. La tria d'aquests materials no té res de casual. Hem d'apreciar que el coure és, poc després de la plata, el material amb més elevada conductibilitat tèrmica, ${ }^{143}$ la qual cosa el fa ideal per a recipients que, amb l'ajut del foc, han d'elevar la temperatura del seu contingut.

Així, doncs, podem observar que el menjar era fregit (paelles), escalivat (graelles), rostit rotativament (asters) o bullit (calderes).

La quantitat d'estris no és gran. Normalment trobarem unes graelles i uns asters a cada casa, tot $i$ que algunes vegades en posseeixen dos exemplars, especialment en el cas dels asters, com ho veiem a la cuina de Jaume Forn. ${ }^{144}$ Pel que fa a les paelles, sense deixar de ser habitual veure'n solament una a cada cuina, és facil trobar-ne juntes un parell. I el que a totes les cuines veurem en més quantitats són les calderes - "cauloria», "cauleria» o "calderia»-. Així, Cànoves, que ens mostra una casa ben proveïda, té quatre calderes i dues paelles, i de la resta d'estris en té un de cada, com a la majoria de cuines. ${ }^{145}$ Hem d'entendre les calderes com un recipient en

139 Vegeu, per exemple, ACB llibre notarial 8, fol. 84 v., on veiem «unum sedile since seun.

140 ACB, llibre notarial 9, fol. 134 v. - 135 r.

141 ACB, llibre notarial 9, fols. 13 v. i 133 v., per citar dos exemples.

142 Com veurem tot seguit, si comparem els estris i atuells de cuina que trobem al començament del segle XIV amb els que es troben a la mateixa ciutat de Barcelona un segle després (veure-ho per exemple a Equip BROIDA, Els atuells de terrissa a les llars barcelonines vers l'any 1400, a Manuel RuU, dir. Ceràmica grisa i terrissa popular de la Catalunya medieval, "Acta Mediaevalia, annex d'Arqueologia» II (1984), pàg. 199-239) els estris i matèries primeres més elementals no canvien gaire, si bé a l'època que estudiem s'aprecia una menor diversitat que no pas una centúria després.

143 G. ColomBO, Manual del Ingeniero, Madrid, pàg. 133.

$144 \mathrm{ACB}$, pergamí 4-10-58a.

$145 \mathrm{ACB}$, llibre notarial 9, fol. $14 \mathrm{r}$. 
un sentit no gens restringit, per això en veurem de diferents mides, i gairebé a totes les cuines en trobarem almenys una de gran i una de petita, encara que a vegades se'ns donen unes altres especificacions, com dir-nos que es tracta d'una «caldera plana», ${ }^{146}$ denominació que ens fa pensar en una cassola.

En algunes cases també podem trobar una mena d'olles de llautó - «pelvis»-. Així mateix, hi ha cuines on veurem un cuinador - «cogonare»-, que sol ser de coure.

Igualment existeix el "vervum» - "verva» en plural-, que no apareix, però, a totes les cuines. Tot i fer-se difícil de precisar- ne la funció, ens en podem fer una idea si pensem que a una mateixa cuina, la de Jaume Cànoves, en podem arribar a trobar tres ${ }^{147}$ i que són fets de ferro, com les graelles, els trípodes i els estris per a la cura del foc.

En el foc hi podem trobar, doncs, trípodes, hem de suposar que per aguantar els estris de cuinar, si bé cal dir que no n'hi havia a totes les cuines. Tampoc no serà estrany veure-hi, com succeeix a casa de Bonanat Marí, "magnis ferris de igne», ${ }^{140}$ relacionats amb l'atenció al foc. En una cuina ben proveïda sempre es situa a la vora del foc un forroll per a remenar el foc i recollir la cendra $i$ un capfoguer destinat a sostenir la llenya i evitar que el foc s'ofegui. Ambdós estris sempre són de ferro.

A les cuines hi sol haver, també, dues o tres llosses - «locias»-, que són unes culleres grans, a vegades de fusta però més habitualment de ferro, amb les quals es devia remenar i distribuir el menjar. I cal esmentar aqui la "giradora», paleta de ferro que complementa la paella, però que era a la pràctica escassíssima, la trobarem ben poques vegades, la qual cosa sembla indicar-nos que la seva feina la devien fer les llosses en la majoria dels casos.

A més, a la cuina hi podem trobar bacins - «bacinum»-, que són uns recipients majoritàriament de llautó però també d'aram. No es solen destinar a cuinar, sovint els veiem com a receptacles de productes. Així, per exemple, a la cuina de Cànoves hi ha un bacinet de llautó ple de sucre de pa. ${ }^{149}$ No hem de relacionar, però, directament el bacinet amb la cuina. Ens apareix més vegades a fora que no pas a dins de la cuina, sovint desat en caixes.

També podem trobar uns recipients amb ansa en un costat $\mathrm{i}$ un broc estret a l'altre costat. Són les «cetra»-setres-. Eren força habituals, les cases riques en tenen moltes, sempre les veiem de llautó $i$ en diferents mides. Ara bé, hem d'anar amb compte per no caure en error d'interpretació: per una banda no hem de relacionar aquestes setres -similars, com es desprèn de la descripció que acabo de donar, als setrills- sols amb olis, i per altra banda hem d'observar que no sempre apareixen a la cuina. Si ens fixem en Cànoves, per exemple, que n'arriba a tenir deu, veiem com tres són clarament a la cuina, però unes altres estan ben desades en caixes bones, $\mathrm{i}$

146 Ho veiem per exemple a $\mathrm{ACB}$, llibre notarial 9, fol. $133 \mathrm{r}$. ple.

147 ACB, llibre notarial 9, fol. 14 r., però podem també veure'n al llibre notarial 8 , fol 84 v., per exem-

148 ACB, llibre notarial, 9 fol. $134 \mathrm{v}$.

149 ACB, llibre notarial 9 , fol. $14 \mathrm{r}$. 
una altra la trobem, al costat d'un sac ple de pebre i d'una bústia amb gingebre, usada com a recipient de citoval.

Un altre estri important és el morter, més encara que la setra, perquè, de morter, n'hi sol haver com a mínim un a cada casa. La majoria dels morters són de coure, encara que n'apareixen també força de marbre, i només en una ocasió n'hem trobat un "de tosca"," a casa de Bonanat Marí, que en té dos més de marbre i un altre de coure. ${ }^{131}$ El complement del morter és la maça de picar - «sua manu»-que, tot i que n'hi ha de fusta, sol ser de coure com la majoria dels morters. Es dedueix facilment que el seu ús a la cuina era molt corrent, i més tenint en compte el gran ús que feien de les salses. ${ }^{152}$ Certament, gairebé sempre ens apareix a la cuina, revelant així la seva funció bàsica.

Podem veure a la cuina algunes ampolles, "' encara que apareixen en ben poques cases. ${ }^{194}$ Molt més habitual serà trobar-hi els estris per a menjar. Per a menjar el que s'ha cuinat veurem els plats. Els que trobem a la cuina són de fusta. Quan s'escriu l'inventari dels béns deixats per Cànoves, es distingeix, en arribar a la cuina, entre escudelles - «scutellae»-, de què es compten vint-i- quatre, i els plats - «discos»-, que sumen dotze de petits i quatre de grans. ${ }^{13}$ Hem d'entendre l'escudella com un plat fondo, o millor dit, un bol, i l'altre com un plat més pla. Però no totes les cuines gaudien de tants plats i escudelles. En algunes gairebé es pot dir que quasi no n'hi ha. I només en les millors cuines trobem l'escudeller, que era una post adossada a la paret de la cuina per a desar-hi les escudelles. ${ }^{156}$

En menor freqüència que les escudelles -a diferència d'aquestes només una o dues en cuines ben proveïdes- trobarem les conques, recipient per a líquids. N'hi ha de grans i de petites, i quan se'ns especifica el material de què són fetes es diu que són d'aram. Hem d'observar, però, que sovint les conques es situen fora de la cuina.

Cal també que tinguem present la servidora, tot i que no n'hi ha a gaires cases. És un recipient, normalment de palma, però també de fusta, específic com a recipient de menjar. Algunes són pintades. Aquestes, amb un toc de luxe, no les

150 ACB, llibre notarial 9, fol. $134 \mathrm{v}$.

151 De tots els morters trobats, cap no era de terrissa, la qual cosa fa pensar que els fets amb aquest material no devien ser, en l'època estudiada, gens habituals, almenys en el nivell social dels inventariats. Faig aquesta reflexió tot pensant en la comprovada existència de morters de terrissa a la darreria del segle XIV (veure Manuel RIU, La ceràmica popular barcelonina del segle XIV. Aportació a l'estudi de les seves formes $i$ marques, i Equip BROIDA, Els atuells de terrissa a les llars barcelonines vers l'any 1400, ambdós a Manuel RIU dir, Ceràmica grisa i terrissa popular de la Catalunya medieval, "Acta Mediaevalia, annex d'Arqueologia» II (1984), pàgs. 145-181 i 199-239).

152 Teresa-Maria Vinyoles arriba a semblants conclusions en el seu treball citat a la nota núm. 14 (pàgina 21).

153 Francesc EIXIMENIS parla d'una taula ben parada amb "les ampolles del vi» (Francesc EIXIMENIS, Ters del Crestià, cap. XCVIII,; a Lo crestià, Barcelona, 1.983, pàg. 113).

154 A la cuina de Jaume Cànoves, sempre ben proveïda, se'n troben 5 (ACB, llibre notarial 9, fol. 14 r.).

155 ACB, llibre notarial 9, 13 v. - 14 r.

156 Ho veiem, per exemple, a la cuina de Pere Rovira (ACB, llibre notarial 8, fol. 57 r). 
trobarem pas a la cuina, i es guarden, potser per a les millors ocasions. Després hi tornarem, en parlar dels objectes especialment preuats.

En l'esmentat inventari dels béns de Jaume Cànoves, es distingeix entre les servidores $\mathrm{i}$ un «servidor», si bé en ambdós casos la matèria primera és la palma i es situen comunament fora de l'àmbit de la cuina. ${ }^{15}$

Pel que fa a coberts, es limiten a culleres de fusta i, a l'igual dels plats, en algunes cuines costa de trobar-ne.

I respecte als ganivets, sempre n'apareixen pocs i no pas exclusivament dins l'àmbit de la cuina. Cal, doncs, apreciar-hi un ús plural i no específic. Els podem trobar diferenciats entre punxó, coltell o ganivet. Solen ser de ferro, i sovint els veiem amb el mànec ennoblit pel material emprat. En Domènec d'Olms té un punxó «cum maneto d.os", i Jaume Cànoves, un "ganiveto de eboro». ${ }^{158}$ És força habitual trobar els ganivets $\mathrm{i}$ els coltells dins la beina. Les beines són de llautó, i també de pell treballada, com és el «camut».

Igualment podem considerar aquí les salseres i els salers. Apareixen molt poques vegades, i sovint fora de l'àmbit de la cuina. El saler el solem trobar d'estany, i molt sovint buit i guardat en una caixa. Quan no és d'estany és de plata, i realment és considerat com un objecte luxós i no el posen pas a la cuina. I pel que fa a la salsera cal dir que sol ser de terrissa, i no l'hem d'imaginar plena de salsa, perquè sol encabir productes alimentaris preuats, com ara a casa de Jaume Cànoves, on veiem una salsera plena de sucre en pols. ${ }^{15 \%}$

Sense que els hàgim de lligar exclusivament a la cuina, és clar, cal tenir present encara altres estris auxiliars. Aquí cal esmentar la "cassia», que és un recipient de coure. En trobarem com a mínim un o dos a cada casa. S'empra per a diferents funcions, i per això es situa tant a la cuina -sovint la veurem a costat del foc- com a fora de la cuina. Amb una ansa es converteix en poal o galleda, i per això solen confondre's ambdós estris, i podem trobar inventariat «unum puteale de cupro sive cassia», ${ }^{(1)}$ mentre que en altres ocasions se'ns diu que la galleda conté la cassia: "unum puteale de cupro cum sua cassia»."1

En algunes cuines, no gaires, hi trobem el gavadal, que és un recipient de fusta que normalment es feia servir per a rentar els estris de la cuina. ${ }^{162}$

Hem d'imaginar-nos a la cuina, per acabar de tenir la visió completa, sempre alguna caixa o, més correntment, un taüt, per tal de guardar-hi els estris i alguns recipients adients, com les cires.

També en l'àmbit de la cuina sol aparèixer el sedàs, que és sempre de seda. En algunes cases n'hi ha més d'un -Jaume Cànoves, per exemple, en té tres-, però altres

157 ACB, llibre notarial 9, fol. 13 r., com exemple.

158 ACB, respectivament pergamí 1-7-3014 i llibre notarial 9, 13 r.

159 ACB, llibre notarial 9, fol. $14 \mathrm{r}$.

160 ACB, llibre notarial 8, fol. $86 \mathrm{r}$.

161 Vegeu la nota anterior.

162 Vegeu-ho, per exemple, a la cuina de Pere Rovira, (ACB, llibre notarial 8, fol. 56 r. i v.). 
ni tan sols no en tenen. El sedàs el veiem relacionat amb la farina, com se'ns diu expressament en alguns inventaris que el recullen. ${ }^{163}$

En algunes cuines trobarem la pastera del pa, que és de fusta, i sovint es protegeix amb una tapa també de fusta. Les cases grans i riques posseeixen amb normalitat més d'una pastera. Pere Rovira en té dues, igual com Bonanat Marí, i Jaume Canoves en té tres, per posar uns exemples. ${ }^{164}$

És molt habitual també posseir a la casa els estris $i$ instruments que ens mostren com fer-se el vi. Tenim, per començar, els cups: Guillem Puig en té un que pot rebre més de 20 somades de collita, i Jaume Cànoves en té molts. ${ }^{165}$ Després tenim el follador, que és la premsa del vi, i les bótes, la cabuda de les quals es mesura en els cafissos, la majoria de les que veiem en pot rebre uns quatre cafissos. Les botetes són similars però de cabuda més reduïda -al voltant d'un cafís-. Cal encara veure les portadores $\mathrm{i}$ les barriles -que actualment anomenem en masculí, barrils ${ }^{166}$-. En alguns casos trobarem un embut per a botes, però apareix ben poc. ${ }^{167}$ També algunes vegades hi veurem mesures per tal de mesurar el vi, que sempre solen ser de coure. $^{168}$

\section{Armes $i$ defensa}

Cal partir de l'obligació real de tenir armes a casa, amb el deure de sortir armat en defensa de l'ordre i del benestar a la ciutat. Ara bé, és clar que no tothom pot permetre's un bon nombre de bones armes. ${ }^{169}$ Haurem de distingir, per començar, entre els objectes que forneixen el conjunt d'armes $i$ els que configuren l'armadura.

D'armes, en el cas més senzill, trobarem llances. Guillem Puig només té dues llances $\mathrm{i}$ una pua. ${ }^{170} \mathrm{La}$ pua l'entenien similar a l'espasa, i per això el notari Vilarrúbies inventaria un "gladium sive puam». ${ }^{171}$ Més corrent és veure l'espasa esmentada com a «ensis». Algunes, luxosament treballades, mostren el puny de cristall. D'altres se'ns diu precisament al contrari: tenen «modici valoris». En el mateix apartat d'armes hem de situar l' «entrementoria», que era de fusta i solem trobar dins de la beina. I pel que fa a la maça -la «massa armandi»-, la trobarem

163 Per exemple, ho podem veure a ACB, llibre notarial 8, fol. $57 \mathrm{v}$.

164 ACB, llibre notarial 8, fol. 57 v. i llibre notarial 9, fols. 133 v. i 14 r.- v. respectivament.

165 ACB, llibres notarials 8 , fol. 86 r. i 9 , fol. 14 v., respectivament.

166 Similar és el celler que podem veure descrit a Carme BATLLE, La casa burguesa en la Barcelona del siglo XIII, dins Carme BATLle dir. La societat barcelonina a la Baixa Edat Mitjana, «Acta mediaevalia, annexos d'història medieval, It (1983), pàg. 21.

167 ACB, llibre notarial 9, fol. 134 r., per exemple.

168 ACB, llibre notarial 9, fol. $135 \mathrm{v}$.

169 És clar que la capacitat econòmica provoca diversitat respecte a les armes de cadascú. Sobre el cas de Barcelona, encara que centrat unes dècades més tard que les que ara estudiem, ho tracta una mica Francisco MARSA, Alarma en la Barcelona medieval, "Historia y Vida", 196 (1984), pàgs. $62 \mathrm{i}$ ss.

170 ACB, llibre notarial 8, fol. $84 \mathrm{v}$.

171 ACB, pergami 1-7-3014. 
només entre els equips d'armar més complets, i sovint amb el mànec enguarnit, com és el cas, per exemple, de les masses de Bonanat Marí i de Jaume Cànoves, que ambdós tenen "cum manubrio picto»."

També podem inventariar una clava. Cànoves en té una de feta amb nervis i guarnida amb el mànec pintat. ${ }^{173}$ I alguna vegada ens apareixen "asconis", uns dards, com llances curtes, per a ser llançats a distància. També en poques ocasions veurem les destrals, que trobem com a "picassa" i tayants - "picatia sive tayatia» ${ }^{174}-$, i que sovint es situen fora del context de les armes. I encara hem d'esmentar la bassegia o bassetja, que era una arma de tir a partir d'una trena flexible i una bosseta on posar-hi una pedra que després, mitjantçant la trena, serà llançada amb força. ${ }^{175}$

L'arma per excel.lència, però, és la ballesta. N'hi ha força. Les més usuals són les d'estrep (anomenades així perquè tenen un estrep per on estreba el ballester amb el peu, mentre amb un croc enganxa la corda i l'estira). Obviament també trobarem els crocs. L'altre tipus de ballesta que veiem és la de dos peus (dita així per la palanca de doble gafa que li fa augmentar la potència). Sobre la composició de l'arc, el trobem de corn, o sia, de banya.

La presència d'aquestes armes, amb el perill d'un ús que desbordi el seu caire defensiu i lúdic, ${ }^{176}$ i aleshores passi a desestabilitzar i trencar la pau a la ciutat, ens ha quedat ben reflectida en les ordinacions municipals, tot palesant les obligades accions del govern del municipi per tal de posar ordre i limitar l'ús de les armes. ${ }^{17}$

Pel que fa a protecció, trobem evidentment els broquers. Els veiem de fusta amb cercles de ferro. A vegades s'espatllen i es continuen guardant, sens dubte amb la intenció d'arranjar-los. Així, Domènec Olms té a casa seva tres fustes de broquers $i$ dos cercles de ferro de broquer. ${ }^{178}$ En alguna ocasió fins $i$ tot podem apreciar darages, com és el cas de l'inventari del mateix Domènec Olms, on se'n registra una de cuir i una altra de fusta. ${ }^{179}$ I també constatem el pavés: Bonanat Marí té una caixa

$172 \Lambda C B$, llibre notarial 9, fols 133 v. i 12 r. respectivament.

173 ACB, llibre notarial 9, fol. 13 r.

$174 \mathrm{ACB}$, llibre notarial 9, fol. $134 \mathrm{r}$.

175 En veiem, per exemple a $\mathrm{ACB}$, pergami 1-7-3014.

176 Del caire lúdic que comporta principalment l'ús de la ballesta ens en parla l'afecció per «ballestejar», molt usual en els «fadrins» (AHCT, Clavaria, 21, pàg. 145), que sovint serà limitada pels consells municipals, com el de Barcelona (IMHB, Fons Municipal, llibre dels consells, 2, fol. 4 v.) o regulada mitjançant el condicionament d'espais expressos per a practicar aquesta diversió, com ho veiem a Tortosa (AHCT, Clavaria, llibres 18 i 21, pàgs. 152 i 145 respertivament).

$177 \mathrm{El}$ problema és general a tot arreu, agreujat per la tensió creada pels diferents bàndols que dividien cada vila o ciutat, i per això tracten de regular-lo tors els consells municipals, tal com es reflecteix en les diverses. ordinacions municipals. Respecte al cas concret de Barcelona en el període que ens ocupa, podem veure-ho de manera breu a Francisco-Luís CARDONA CASTRO, La ciudad de Barcelona en el siglo XIV a través de sus ordenanzas municipales, "Cuadernos de Historia Económica de Cataluña», XVII (1977). Pàg. 62.

178 ACB, pergamí 1-7-3014.

179 ACB, pergamí 1-7-3014. 
on sols hi guarda el pavés. ${ }^{\text {(*) }}$ El que més trobem, però, és esmentar solament escut - veurem tant «scutus» com "clipeus»-, sense que se'ns n'ofereixin més detalls.

Sobre l'arnès, hem de començar dient que no sempre apareix sencer, amb totes les seves peces, excepte entre els béns de les famílies realment riques. En el cas de les cuirasses, sempre són ben guardades dins d'una caixa i embolicades amb un cobertor de roba. Aquest cobertor no és una peça qualsevol, sol ser valuosa, la qual cosa ja ens indica la consideració que tenien de la cuirassa. En el pitjor dels casos es tracta d'una peça de lli, que sovint trobem de color vermell, però si es pot es té en teles més preuades. Jaume Cànoves en té tres, de cuirasses, una la guarda amb un cobertor de Ili, però les altres dues les cobreix amb un cobertor de samit vermell en un cas $i$, en l'altre, amb un cobertor de fustany llistat. Les altres peces de l'arnès també es resguarden amb el mateix sistema. Així, el mateix Cànoves guarda una gorgera "cum cooperta fustani listati»."

Sempre trobem allò necessari per a protegir bé el cap. Veiem el capell de ferro ( «casc d'ales amples i caigudes que protegeix el crani», en definició de Martí de Riquer ${ }^{182}$ ), i en algun cas ens apareix el capell d'almogàver, que devia protegir el rostre amb els seus "fili nigri»..$^{181}$ En un altre cas ${ }^{131}$ trobem fins $i$ tot una "barbuda», casc que protegia cap i coll. També tenim, i amb molta més freqüència, bacinets ( "casc ovoide originàriament portat sota l'elm», amb les mateixes paraules de Martí de Riquer), que solem veure de tela, com els que té Domènec Olms, que és «de panno bruno". ${ }^{18 s}$ La protecció del cap respecte a la pròpia armadura també queda garantida. Amb aquesta finalitat s'empren els capells d'armar, les barretes i el capell jubat. En tots tres casos es tracta d'una tela col.locada entre la peça metàl.lica i el crani, i que inventarien de color blanc, vermell, vermell fort i cru pàl.lid. Les teles emprades són de lli o de roba barrejada, segons ho veiem en els casos en què es fa constar. També es feia servir per a aquesta finalitat el bonet, un barret baix que acostumem a veure «de panno rubeo».

Trobem la gorgera, destinada a protegir el coll. La trobem de malla. Hi veiem també espatlleres, per a cobrir les espatlles. I constatem, encara que no gaire sovint, el camisoll - "camisollum de ferro»-, que hem d'entendre com una cota de malla amb mànigues i llarga. Igualment, les cuirasses, que ofereixen protecció al cos, són poc freqüents (malgrat que en una sola casa, la de Jaume Cànoves, se'n guardin tres). També apareixen les cuixeres per a guardar les cuixes, les gamberes per a defensar les cames i els guants de ferro per a preservar les mans. Sempre que d'alguna d'aquestes peces se'ns indica el seu material de composició, se'ns diu que és de ferro.

Especial interès té la braçerola, que protegia gran part del braç. Observem que

180 ACB, llibre notarial 8, fol. $86 \mathrm{r}$.

181 ACB, llibre notarial 9, fol. $13 \mathrm{r}$.

182 Marti de RIQUER, L'armès del cavaller. Ammes $i$ armadures catalanes medievals, Esplugues de Llobregat, 1968, pàg. 233.

$183 \mathrm{ACB}$, pergamí 1-7-3014.

184 ACB, llibre notarial 9, fol. $135 \mathrm{v}$.

185 ACB, pergamí 1-7-3014. 
és una peça acurada, sobretot quan porta pintat el «signum» del seu propietari. ${ }^{1 \%}$ És interessant d'observar que Jaume Cànoves té uns bacinets $\mathrm{i}$ una braçerola d'un tipus concret que es defineix com a pisà, fent referència a la ciutat toscana. ${ }^{187}$

Els perpunts protegeixen tant el cos de l'armat com el de l'animal quan hi és. Tots els que hem trobat, tant per al cavaller com per a la bèstia, són «de sindone rubea». En alguns casos s'especifica que porta adjunt un capell amb la mateixa finalitat. Unes altres vegades la protecció del cos respecte a l'armadura ve donada per la «camisa de guarnir».

\section{Salut, bigiene i benastruganfa}

En primer lloc podem constatar la presència d'una sèrie de productes que ens denoten uns usos relacionats amb la salut. Així, Jaume Forn té dins d'un cofre "quatuor capcie de cunfics vacue», ${ }^{18}$ que, com apunta des d'un punt de vista lèxic l'obra d'Alcover-Moll, hem de relacionar-ho amb elaboracions aromàticomedicinals, segurament amb components de sucre. ${ }^{189}$

En aquest mateix sentit no podem passar per alt que a casa de Jaume Cànoves trobem sucre, tant en pols com compacte -conglomerada ("pa de sucre»)-, igual com, a part de les espècies que té a les botigues per raó del seu negoci, dins de casa seva veiem espècies que, tot $i$ tenir una clara $i$ habitual utilitat a la cuina, ${ }^{190}$ són susceptibles d'un ús medicinal $\mathrm{i}$ aromàtic, com el citoval, el gingebre $\mathrm{i}$ el mateix pebre. ${ }^{191}$ I segurament també hem de tenir aquí present l'existència, encara que escassament representada, dels perfumadors, que analitzarem entre els objectes de plata. $^{192}$

Entre la higiene i la medicina hem de situar l'ús del bany. En les millors cases trobem banyeres - «tina abta ad balnendum» o també "portatoria ad opus balneandi" ${ }^{193}$-. I una mica més corrent que la banyera és el lavacap, relacionat preferentment amb la higiene masculina. Era sempre de ferro i esdevingué un element d'ostentació, per això el tornarem a tractar entre els objectes preuats.

Trobar aquests estris d'higiene ens lliga amb el fet que en aquella època el bany era en auge com a teràpia medicinal. Segons Cardoner ${ }^{194}$ això es devia a la tasca

186 Ho veiem, per exemple, a $\triangle \mathrm{CB}$, llibre notarial 9, fol. $13 \mathrm{r}$.

187 ACB, llibre notarial 9, fol. $13 \mathrm{r}$.

188 ACB, pergami 4-10-58 a.

189 A. M. AlCOVER - F. B. MOlL, Diccionari Català-Valencià-Balear, III, Palma de Mallorca, 1968, pàg. 390 .

190 Josep GArCin I FORTUNY, La condimentació a la Catalunya medieval. Aportacions per al sen estudi, a Alimentació $i$ societat a la Catalunya Medieval , Anuario de Estudios Medievales, anex 20" (1988), pàgs. 68-69.

191 ACB, llibre notarial 9, fols. 12 r. i ss. r.).

192 El veiem de manera més clara entre els béns de Bonanat Marí (ACB, llibre notarial 9, fol. 134

193 ABC, llibre notarial, 9, fols 14 r. i 134 r., respectivament.

194 Antoni Cardoner i Planas, Historia de la Medicina en la Corona de Aragón (1162-1479), Barcelona, 1989, pàg. 155 . 
personal d'Arnau de Vilanova des que l'any 1266 retornà a Catalunya. I el cert és que Arnau de Vilanova en el seu «Regiment de Sanitat» dóna una sèrie de consells concrets sobre perquè, com i quan banyar-se, ${ }^{199}$ i de tina per a banyar-se sabem que ja en disposa el futur Pere el Gran l'any $1268,{ }^{196} \mathrm{i}$ dècades després n'anirem veient entre els alts estaments. ${ }^{197}$

Cardoner ${ }^{198}$ creu que és «l'escassa confiança en la dosificació de les medecines» el que facilità l'èxit dels mètodes curatius externs, considerats menys perillosos, com és el cas del bany. Igual consideració, continua el mateix autor, rebien el mètodes «evacuants, que en realitat corresponen només a les malalties amb vici o alteració humoral, en les quals hom podia obtenir l'eliminació de la matèria morbosa mitjançant sudorífics, purgants, escorificacions, ventoses, aplicacions de sangoneres $\mathrm{i}$-en primer lloc- la sagnia». ${ }^{199}$ Podem observar facilment en els tractats de l'època, per exemple, com sovint es recomana la sagnia. ${ }^{200}$

Aquest ús tan estès de la sagnia també ens apareix reflectit en els inventaris. Existia una bena específica que s'aplicava sobre el lloc on es realitza la sagnia: és la bena de sagnar. ${ }^{201}$ No n'hi ha, però, a totes les cases, la qual cosa fa suposar que sovint la portava el sagnador -sempre un barber, ${ }^{202}$ que havia d'actuar per indicació del metge ${ }^{203}$ - o que, en cas de no disposar d'aquesta bena, es devia tractar de fer el mateix amb un altre drap similar, encara que el problema no es plantejava gaire perquè moltes sagnies es feian a casa del barber. ${ }^{204}$

Però la sagnia no es podia fer de qualsevol manera ni en qualsevol moment. Comenge va situar les sagnies entre els avortius, ${ }^{205}$ i es temia fins $i$ tot la mort de les

195 Arnau de Vilanova, Obres Catalanes, edició a cura de Miquel Bathlori i Joaquim Carreres, II, Escrits Mèdics, Barcelona, 1947. Pàgs. 115 i ss.

196 Joaquim MIRET y SANS, Viatges de lÍnfant Pere, fill de Jaume I, "Butlletí del Centre Excursionista de Catalunya», XVIII (1908), pàg. 175.

197 Així, per exemple, sabem que el 1367 la reina Elionor féu comprar a Lleida una tina per a banyar-se (ACA, Reial Patrimoni, Mestre Racional, vol. 489, fol. 62 r. i v.).

198 CARDONER, ob. citada, pàg. 183.

199 Ibidem.

200 Podem veure, per citar un cas concret, Joan VENY, Patit tractat sobre lo regiment en temps de Hepidèmie, «Homenatge a Antoni Comas», (Barcelona, 1985), pàgs. 563 i 564.

201 ACB, pergamí 1-7-3014.

202 Lluís GARCIA BALleSter, La Medicina a la València Medieval, València, 1988, pàgs. 17 i 57 i ss.

203 A Vic ho manaran les ordinacions municipals (S. CONILL, Ordinacions sobre bans y penes a Vich en el segle, XIV, «Butlletí del Centre Excursionista de Vich», V (1925-1928), pàg. 117).

204 És ben clar des del moment que algunes ordinacions municipals es preocupen per les conseqüències higièniques que comporta que els barbers tenen molta usanch a la porta de son alberc ho de son obradorn, especialment quan cap al migdia hi concorren les mosques, tal com ho veiem a Vic (vegeu la nota anterior) o, de manera més genèrica, a Girona (Jaume CoDINA, Sabí PERIS, Ordinacions de Girona de l'any 1358, Annals, XXVIII (1985-1986), pàg. 202).

205 L. COMEnge y Ferrer, La Medicina en el Reino de Aragón. Siglo XIV, (edició facsímil), Valladolid, 1974, pàg. 83. 
sagnies fetes en excés ${ }^{206}$ o en mal moment. ${ }^{207}$ Quan es pot fer una sagnia?. Doncs quan ho indiqui la posició de la lluna. Aquesta importància donada a la lluna és cabdal per a entendre la vida quotidiana en el temps $i$ en la societat que ens ha llegat els inventaris que ara estudiem.

De la lluna depèn tot. Abans de realitzar un viatge, un negoci, un casament, una sagnia... cal consultar quins són els dies propicis i quins els nefastos, que marquen fins i tot el destí dels nounats i la viabilitat dels somnis. Podem veure-ho al conegut Atles de Cresques Abraham ${ }^{208}$ que, tot i ser un xic posterior cronològicament, ens reflecteix una realitat ben viva ja al començament de segle ${ }^{209}$ i que es sentia molt intensament a tot l'Occident Medieval, com ja ho apuntà Millàs Vallicrosa. ${ }^{210}$ No és, doncs, estrany que la medicina es basés plenament en l'astrologia, i més quan aquest procediment venia avalat pel mateix Arnau de Vilanova $i$ es justificava fins $i$ tot a partir d'Aristòtil i Averroes. ${ }^{211}$ I tampoc no sobtarà, per tant, que arribem a trobar el rei Alfons el Benigne prohibint als barbers de València sagnar quan la lluna ho desaconselli. ${ }^{212}$

I si insistim en el domini global que té la lluna sobre tots els afers que home o dona puguin fer, comprendrem la necessitat de poder conèixer quins són els dies que la lluna marca, ${ }^{213} \mathrm{i}$ com cal fer el còmput de la lluna. Els instruments per poder portar aquest càlcul a terme també acompanyaven la vida dels nostres personatges inventariats.

Són les «tabule fustee de compoto» i els «computatorium de fuste» o, més clarament, "computum lune». ${ }^{214}$ Aquestes taules de càlcul, tal i com ens les descriuen els notaris en inventariar-les, portaven dues rodes de fusta per tal de calcular la longitud diària del sol i les posicions lunars i després poder aplicar-hi els

206 «Lo marit (que era metge) féu venir lo barber e manà a la dona que es sagnàs, car la sagnia era bona; e quan li hagueren treta una bona escudella de sang, dix la dona que bastava. Dix lo marit:

-Dona, dues altres escudelles n'havem a treure, e llavors serets ben sana (...)

E diu que tretes les dites tres escudelles de sang, de continent la dona morín.

(Francesc EIXIMENIS, Ters del Crestià, cap. XCVIII; a Lo crestià, Barcelona, 1983. Pàg. 113).

$207 \mathrm{Al}$ començament del segle XV trobaren un procés contra un metge a Barcelona per la mort d'un pacient per aquesta raó (CARDONER, ob. citada).

208 El Atlas Catalán de Cresques Abrabam, Barcelona, 1975.

209 Julio SAmsó i Juan CaSANOvas, Cosmografía Astrológica y Cotidiana, dins de l'edició de lÁtles de Cresques Abraham esmentada en la nota anterior, pàg. 27.

210 J.M. Millds Vallicrosa, Las Tablas Astronómicas del Rey Don Pedro el Ceremonioso, Madrid, 1962.

211 CARDOner, ob. citada, pàgs. 205-227.

212 ACA, Cancelleria, Registre 1902, fol. 154 r.

213 Trobarem al llarg de tot el segle XIV llibres notarials on al primer full es consignen quins seran els dies nefastos de l'any. Com a exemple ben clar podem veure ADPO, 1B-161. I també podem observar com Pere III farà constant ús d'aquests coneixements (ACA, Cancelleria, registre 1168, fol. 69, per exemple).

214 ACB, pergami 4-10-58 a, llibre notarial 8, 57 v. i pergamí 1-7-3014, per citar respectivament on es poden veure les expressions aquí ressaltades, però els exemples són molts: les taules de càlcul apareixen en la majoria dels inventaris consultats. 
coneixements astrològics. Aquestes rodes concorden plenament amb les que per les mateixes dades eren freqüents a tot Europa. ${ }^{21}$

\section{Objectes de luxe i ostentació}

És interessant d'observar, com ja he deixat entreveure abans, que una important font d'objectes de luxe rau en estris originàriament relacionats amb l'alimentació. ${ }^{216}$ Són els coberts, tasses, copes i gots que no he volgut esmentar entre els estris de cuina perquè rarament els trobem allà, són sempre ben guardats en les caixes fora de la cuina i poques vegades o cap s'empren en la seva funció originària. ${ }^{21}$

El que més trobarem són les copes de plata. Totes les llars que poden permetre's un luxe comencen per aquest i per les culleres igualment de plata, de les quals ja parlarem. Les més bones d'aquestes copes- «ciffum» o «ciphum»-són les que duen la marca o punxó de procedència ${ }^{218}$ : Jaume Cànoves en té cinc de marcades amb "marchas Barchinone» -una d'aquestes, a més, amb un motiu ornamental de florsi tres amb la «marca Janue» (de Gènova) ${ }^{219}$. Marcar els treballs d'argent era a Catalunya una concessió reial que prestigiava els municipis i els seus argenters, i per aquesta raó es demanava al rei tot prenent com a model la ciutat de Barcelona, tal i com succeix, per exemple, a mitjan segle a Vic. ${ }^{221}$ Els reis no semblen gaire esquerps a donar aquest privilegi (el reben, per exemple, Cervera i Tàrrega el 1315 o, més endavant, el 1383, Manresa) i per això ens diu Duran i Sanpere que el privilegi «era atorgat amb certa liberalitat i no sempre amb eficàcian. ${ }^{221}$

En el millor dels casos, la copa d'argent és banyada amb or, daurada, com la que té Guillem Puig o com les dues que posseeix Bonanat Marí. ${ }^{222}$

Podem imaginar-nos la grandària d'aquestes copes gràcies a conèixer a vegades el seu pes, que sol girar entre un marc $\mathrm{i}$ unes deu unces barceloneses.

Obviament les copes es guarden dins les caixes, ben desades. La manera més

215 CORDOLInNi, Contribution à la littérature de comput ecclesiéstique au moyen àge, «Studii Medievaliw, III (1961), esmentat per Samsó i Casanovas, ob. citada, p. 30.

216 Situació que corroboren altres estudis coetanis, $i$ fins $i$ tot a vegades tots els objectes de luxe inventariats tenen relació amb la cuina o la taula (vegeu per exemple, Joan-Eusebi G^RCIA I BıOSCA, Un rencant» de la casa dels Sanaijja a Lleida, any 1343, „Palestra Universitaria», III (UNED Cervera, 1988), pàg. 265).

217 Només trobem, de tots els inventaris analitzats, Jaume Forn amb una tassa $i$ una copa de plata a la cuina ( $A C B$, pergami 4-10-58a). Tots els altres que en tenen no les guarden a la cuina.

218 També ho podem veure en altres inventaris coetanis: Carme BATLlE i Angels PARÉS, El castell de Sitges a la mort de Bernat de Fonollar (1326), «Acta Mediaevalia, Annexos dÁrqueologia Medieval, Annex 3n (1986-1987), pàg. 160.

219 ACB, llibre notarial 9, fols. 12 v. -13 r.

220 Pere III el 1351 concedirà que els consellers i prohoms de Vic escullin un bon home que, tal com es fa a Barcelona, marqui «taceas, cupas, scutellas, cloquearia et alia quelibet vasa et opera argentea que in eisdem civitatis et locis per argentarios ibidem existentibus fabricantur et operantur" (AHMV, Llibre de Privilegis XIX, fols. 66 v. -67 r.).

221 Agusti Duran I SANPERE. El llibre de Cervera, Barcelona, 1977, pàg. 181.

222 ACB, llibre notarial 8, fol. 12 v.; i llibre notarial 9, fol. 130 r. respectivament. 
idònia, com ja ho he assenyalat abans en parlar dels recipients, és posar-les dins d'un estoig de cuir, confeccionat expressament amb aquesta finalitat, i que a vegades s'esmenta com "conservatorium». ${ }^{223}$

Amb menor incidència també trobarem tasses de plata. No n'hi ha tantes i, igual com els esmentats "ciphum» d'argent, cal sempre cercar-les en una caixa ben guardada. Són més petites que les copes, el seu pes és de 4 o 5 unces barceloneses.

Cal dir que en cas de penyora o de manlleuta, les peces que més veiem empenyorades són precisament les copes $\mathrm{i}$ les tasses de plata, la qual cosa ens pot donar una idea de la seva vàlua. ${ }^{21}$

Ja he esmentat abans la importància dels salers, que apareixen en poques cases $\mathrm{i}$ que no es troben precisament a la cuina. La majoria són fets d'estany, encara que els millors són de plata $i$ es guarden en caixetes. ${ }^{22 s}$

Encara més rar és el "perfumador», recipient dins del qual es devien cremar matèries oloroses i que trobem de plata. Apareix, però, ben poques vegades. ${ }^{226}$

I allò que apareixerà tant com les copes d'argent o més, són els coberts de plata. Els trobarem normalment dins de caixetes $i$ algunes d'aquestes caixetes són en si mateixes una joia, com la «caixeta modica de osse» on Jaume de Forn guardava "unus gavinet parvus de argento». ${ }^{227}$

Però els coberts d'argent que més trobarem no són pas els ganivets, que en realitat són molt escassos, sinó les culleres - «cloqueariis argenti»-. Veurem les culleres dins de caixetes ben desades a dintre d'una caixa. Es fa interessant d'observar que semblen, potser encara més que les copes d'argent, un luxe bàsic i inicial: així que es pot tenir un luxe, de seguida trobem les culleres de plata $-i$ mai no es sol trobar més d'una dotzena de culleres en una mateixa casa-, però a la majoria de les cases molt riques, de culleres de plata, en trobem poques, prefereixen fer ostentació de riqueses més preuades, com les pedres precioses que veurem ben aviat. ${ }^{228}$

Cal dir també que entre la vaixella de la casa hi ha atuells que no són fets amb metalls preciosos, però que es guarden separadament dins de caixes i fora de la cuina. És el cas de les bones servidores. No són fetes de cap metall, són de fusta, però és fusta pintada, $i$ en alguns casos s'especifica una obra més polida, com una «servidora depicta de opere bugie», amb un estil que es refereix precisament a la ciutat nordafricana. ${ }^{229}$

223 ACB, llibre notarial 9, fol. 12 r., per exemple.

224 Podem veure-ho a $A C B$, llibre notarial 9, fol. 12 v. o pergami 4-10- 58a, entre d'altres.

225 ACB, llibre notarial 9, fol. 143 r.: dos salers de plata en una caixeta.

226 Vegeu nota 192.

227 ACB, pergami 4-10-54 a.

228 Bonanat Marí té moles objectes de luxe i sols una cullera d'argent trencada, i Pere Rovira ja hem vist abans que té robes mole luxoses, però no té culleres de plata. En canvi, Jaume Cànoves té una dotzena de culleres d'argent (ACB llibres notarials 9, fol. 133 r.; 8 fol. 56v. i ss; 9, f. 12 r. i ss. respectivament), per citar uns exemples.

229 ACB, llibre notarial 9, fol. 13 r. 
En aquest mateix sentit cal apreciar com també es guarden a part i fora de la cuina les escudelles que no són de fusta. Aquestes escudelles a vegades són de plata, però les escudelles d'argent apareixen molt escadusserament. ${ }^{230}$ Més habitual és trobar-les d'estany. I cal que aquí sapiguem adonar-nos de les vaixelles "a conjunt», on es combinen les culleres de plata i les escudelles d'estany. Ho podem veure entre els béns de Jaume Cànoves: en una caixa té una caixeta amb vuit culleres de plata, les quals fan joc amb les escudelles d'estany que guarda dins la mateixa caixa, i que són vuit escudelles grans i vuit de petites. ${ }^{231}$ Per acabar de copsar aquest fet, haurem de tenir present que, segons Duran i Sanpere, l'estany era molt estès i molt valorat no sols a Barcelona sinó també per tot Europa. ${ }^{232}$

Deixant ja a un costat aquests tipus d'objectes preuats relacionats, encara que a vegades només com a reminiscència, amb l'alimentació, cal que vegem els objectes amb una finalitat exclusivament d'ostentació de la riquesa. Aquí trobarem bàsicament anells.

Els anells són molt abundants, moltíssim: Bonanat Marí en té 18, Jaume Cànoves en té 14 i Berenguer Olms, 5, per citar-ne uns exemples. ${ }^{233}$ Tots són d'or, no n'apareixen d'altres materials, i estan guardats en caixetes, algunes d'especialment luxoses, com la caixeta d'ivori on Jaume Forn guarda el seu anell d'or. ${ }^{234}$

És difícil trobar un anell d'or que no es complementi amb alguna pedra preciosa 0 , en menor nombre, amb una perla. ${ }^{235} \mathrm{Cal}$ que tinguem present que les pedres precioses no sols tenien una finalitat guarnidora, sinó que es consideraven portadores de moltes virtuts, tal $i$ com ho reflectien els lapidaris, que tant proliferaren a la Baixa Edat Mitjana, encara que a Catalunya no ho feren tant com en altres indrets europeus. ${ }^{236}$

La pedra que més trobarem és el safir, ${ }^{237}$ i amb una freqüència no gens r.).

230 Per exemple,podem veure'n entre els béns de Bonanat Marí (ACB, llibre notarial 9, fols. 132 r. - 135

231 ACB, llibre notarial 9, fol. $13 \mathbf{v}$

232 Agustí DURAN I SANPERE, Barcelona i la seva bistòria, II, Barcelona, 1972-1975, pàg. 394.

233 ACB, llibre notarial 9, 132 r. - 135 v. i 12 v. i pergamins 1-7-3014 i 4-10-58 a respectivament.

234 ACB, pergamí 1-7-3014.

235 Es molt més habitual trobar pedres - «lapidesn- completant l'anell que no pas perles (malgrat que no són incompatibles, hi ha anells amb pedra i perla) i, tot i que n'inventariem amb perles soles (per exemple a ACB, pergamí 4-10-58 a), es nota que guarneixen més les pedres.

236 Joan GILI, Introducció al Lapidari. Tractat de les pedres, Oxford, 1977. Pàgs. XV i ss.

237 «Safir és semblant a color serè, e és apellat cirtes per ço com es trobat en les partides de Síria. E aquells qui són trobats en India, ço és en lo flom de perays han color d'atzur e no són transpertius, són de magor car Deus lus ha dada virtut que és sobre les altres pedres totes. E qui.l porta conforta lo cors e té los membres sans, e val contra mal d'ulls, e qui'l porta no pot ésser enguanat. E tol envege e desliure hom de presó, e dóna gràcia han aquell qui.l porta de Reys e de grans senyor e fa ésser plasent e fa.l ésser amat d'aquells senyors, e dóna-li gràcia de totes gents, e fa-li ésser lo senyor favorabla a las suas preguarias, e conserva la pau e val contra art de gromància, e fa-li somiar divina responça, e sana malaltia de cors, e refrena la calor e restreny la suor. E si d'aquella pedre serà picada e posada sobre nafre, sànala e nala los nervis e tol dolor de front, e sana mal de guola e de lengua inflada, e sana la apostema e la naxenssa un que siaw. (Lapidari. Tractat de pedres precioses, edició de Joan GILI, Oxford, 1977. Pàgs. 5-6). 
menyspreable també trobarem la turquesa. ${ }^{238}$ En els millors casos aquestes pedres blavoses ${ }^{239}$ es veuen complementades amb alguna perla. Més rarament apareix l'esmaragda, ${ }^{240} \mathrm{i}$ ben poques vegades veurem el robí ${ }^{241} \mathrm{i}$ encara menys la cornalina (una àgata vermellosa) ${ }^{242} \mathrm{i}$ el granat. ${ }^{243}$ També en ben rares ocasions es presenta embellit l'anell d'or "cum litteris ibi sculptis». ${ }^{24}$

L'or, fora d'aquests anells, és difícil de trobar-lo. Veiem, entre els béns que havien estat de Domènec Olms, un tros de trena d'or, que hem de relacionar amb els brodats, ${ }^{243}$ tot considerant-ho dins de la indústria de filat d'or que Duran i Sanpere ja situa a la Barcelona del segle XIV. ${ }^{246}$ També trobem entre els béns de Bonanat Marí "trocciis de aurifrisio veteri suficientibus ad guarnimentum unius epitogerie domine». ${ }^{247}$ I ja he esmentat l'ús de l'or per a banyar objectes de plata. Cal afegir que també el llautó es pot complementar amb un daurat. L'esmentat Bonanat Marí té dues almorratxes - una mena de càntirs- de llautó amb parts daurades. ${ }^{24}$

La valoració dels metalls preciosos és evidentment molt elevada. Per això es

238 «Turquesa són de dues colors, les unes retrahen a verdor e les altres a blavor, e aquestes són les millors e són trobades en les parts dÓrient. E la lur virtut és aytal que tot cavaler qui.n toch la civada o la viande o l'aygua al cavall ho a quolque bèstia que ell haga, no pot ésser senfusa. Ne null homa qui la aport no farà male viande, e fa alegrar la vista e conforta l'estomach. E no pot ésser ombrat de dimonis ne de mal vent ne de núvol de mala ne de ombre, e val contra fatiles, que aquell a qui un les fard no poran noure, e tornaran dessús aquell qui les farìn. (Lapidari..., pìgs. 22-23).

239 Un detall a observar és que les dues pedres precioses més emprades basen el seu atractiu estètic en tonalitats del color blau.

240 «Meracda ha color de verdor e són de moltes color, mas aquells qui han presa bé color de verdor. E si són al sol o a la hombre tinyan l'aher la un ells se estan e aquests meracdas són los milors e los pus naturals, e la lur virtut és aytal que qui.l porta en aur fi que fa créxer riqueses e tol l'om de angustia e de tot mal e dona-li alegranssa e fa la sua peraula agradable e dóna bona fama. E tol febre e tot luxxúria, e si hom la porta e, tinent-la ell, hus ab fembre, deu fer la pedra molts trossos de si matexan (Lapidari... pàgs. 9-10).

241 « La sua virtut és la de créxer riquesses, e fa hom axalsar en honor. Aquesta pedra és de natura de sol, e val en hamor de Reys e d'altres barons, e deu ésser encastat en fin aur, e deu ésser portat en la dreta part del cors, e deu ésser posada o mesa sota la pedre del anell una erba qui.s apella sitoval, şo és la terra major». (Lapidari..., padgina 3).

242 «Cornellina ha color de sanch. La sua virtut és estrectiva ho restrectiva e fa estanchar sanch de tot membre e a sanch flux de nas. E aquella qui ha color de sanch de carn és sacra e millor, e val molt a fembre qui la aport com ha de son temps ho de se flor" (Lapidari..., pàg. 20).

243 El lapidari anglès del segle XV Bodleinan MS. e Museo 52, folis 44-47 (citat per Joan GILI, Lapidari..., pàg. 36) emet l'equivalencia «gergonsa sive granatusn. Per aixó llegim que en les girgonses *la lur virtut és que tenen l'aher temprat e dónen bonna gràcia e aquell qui 1 l porta. E val contra a verl a fa l'om graciós a les hostes, e déu ésser encastat en aur fi. E deu ésser posada là hon la pedre sía encastada i erba qui és apellada seldoni o seldonia e aquesta erba conserva-li la virtut» (Lapidari..., pag. 9).

244 Ho trobem en Bonanat Marf, que a més és l'unic on podrem trobar, en diferents anells, totes les esmentades pedres precioses (ACB, llibre notarial 9, fol. 134 r.).

245 Similarment ho podem veure a Agustí DURAN I SANPERE, Barcelona i la seva bistdria, II, Barcelona, 1972-1975, pàg. 160.

246 Ibidem, pàg. 344.

247 ACB, llibre notarial 9, fol. 134 r.

248 ACB, llibre notarial 9, fol. 132 bis v. 
guarden fins $i$ tot les peces trencades, $i$ així veurem anells d'or trencats $i$ «argentum fractum» també desats. De totes maneres, no ens ha d'estranyar llegir, a vegades, poc valorades les pedres precioses: davant d'anells d'or amb pedres sovint el notari no dubta a valorar que, d'aquestes pedres «ibi insertis», "nullus est magni valoris". ${ }^{24)}$

Cal considerar també aquí un estri fet sempre de ferro: el lavacap, que, com ja he apuntat abans, es relaciona amb l'ostentació i amb la higiene masculina. Esdevingué normal que en les «sposalles o affermalles», o "depuys tro que sien estats nuvis», la núvia rebés del nuvi anells, mentre que ella li oferia un lavacap o "altres joyes». El Consell municipal de Barcelona, en els seus bans on regulará els costums $i$ el luxe en els casaments, prohibirá aquest intercanvi de regals. ${ }^{251}$

Uns altres elements aptes per a convertir-los en joia tenen alguna finalitat pràctica en el vestit. Són en primer lloc els afiblalls $i$, sobretot, els teixells, idonis per a posar-hi pedres precioses i perles, com ja ho hem comentat en parlar dels complements del vestit.

Hem parlat també de les corretges, que es poden presentar recobertes amb plata i que ofereixen material per a guarnir amb les fíbules i les virolles. Cal que detallem aquí que algunes «munitas argenti» s'enriquien amb platons, que són unes petites bolles d'argent que s'hi afegien amb una finalitat únicament luxosa. Per a fer-nos-en una idea, observem la corretja banyada en plata que té Pere Rovira: és formada per tres dotzenes de platons de plata i compta amb una mosqueta -per a subjectar el ganivet - igualment de plata, a més d'una fíbula. ${ }^{251}$ les.

També cal apreciar aquí els orals, que, com ja he dit, es guarnien amb per-

Sobre les perles hem de tenir present que potser la nostra imaginació pot deformar-ne la imatge. Perquè no eren esferiques i tampoc no eren blanques, el seu color corrent, tal i com el trobem, és un color verdós. Anaven «incastate sive enfilate" ${ }^{292}$ en un altre material, i era habitual posar-ne més d'una, tasca pròpia de brodadors. ${ }^{25 \prime}$ El preu n'era molt elevat, les veiem vendre a raó de cinquanta-dos sous per cada unça de pes. ${ }^{2 s 1}$

Ens resta, entre els complements luxosos de la roba, parlar dels botons. La majoria són d'argent, però també en podem trobar d'argent banyats d'or -daurats-, $n$ 'hi ha de cristall $i$ algunes vegades - poques- els trobem de corall. ${ }^{2 s s}$ Pensem, per tal

249 Podem veure-ho, per exemple, a $\Lambda$ CB, llibre notarial 9, fol. 12v.

250 IMHB, Arxiu del Batlle i el Veguer de Barcelona, X-I, fol. 3 r.

251 ACB, llibre notarial 8, fol. $56 \mathrm{r}$.

252 ACB, pergamí 1-7-3014.

253 Vegeu sobre aquests brodadors a Barcelona A. Duran i Sanperc. Barcelona... pàg. 313. I podem apreciar un cas concret de brodadors, encara que unes dècades posteriors al temps on hem centrat aquest estudi, a David Romano, Los Surí, judios de Huesca y perleros de la reina de Aragón (1350-1372), «Sefarad» XI (1980), pàg. 256.

254 ACB, pergami 1-7-3014.

255 De corall, només n'hem trobats tres entre els béns de Pere Rovira (ACB, llibre notarial 9, fol. 57 v.). 
de copsar què s'entenia per botó, que quan els veiem posats a la roba els trobem en grans quantitats, sempre comptades per dotzenes, complint una finalitat decorativoluxosa: ja he dit abans que Pere Rovira té una túnica amb dues dotzenes de botons de plata i una sobretúnica on se'n compten tres dotzenes. ${ }^{2 s /}$ Aquesta mateixa finalitat luxosa farà que, a diferència de guarniments més pràctics, com els teixells o els afiblalls, els botons sovint els trobem fora de la roba i guardats dins d'una caixeta tal i com es fa amb qualsevol joia. Això ho veurem fer tant amb els botons de plata $i$ daurats -Jaume Cànoves guarda, en una caixeta petita juntament amb altres coses preuades, tretze dotzenes de botons de plata daurats ${ }^{257}$-, com amb els pocs que hi ha de corall ${ }^{258} \mathrm{o}$ amb els botons de cristall. ${ }^{259}$ Pel que fa a models d'aquests botons, sols sabem que una de les modalitats era la de "miges magranes", ${ }^{2(x)}$ com ho són les cinc dotzenes de botons d'argent que compten entre els béns de Bonanat Marí. ${ }^{201}$

Més endavant, el Consell municipal de Barcelona maldará, mitjançant els bans, per a limitar qualsevol mostra d'ostentació (perles, fils d'or, argent...) en les robes i llurs complements. ${ }^{262}$

Sense deixar de parlar del treball dels argenters, cal esmentar que només en una ocasió, a casa de Bonanat Marí, trobem «quandam Agno Dei guarnite de argento", ${ }^{263}$ que es tracta d'un reliquiari que duu gravada la imatge de l'anyell representant Jesucrist.

També es fan presents, encara que poc representats, els objectes de «crestayl». El cristall, que acabem de veure emprat com a botó, és considerat com una pedra preciosa, a l'igual de les que hem vist abans en els anells. ${ }^{2(s+1}$ Per això, tot i que mai no es fa servir per a adornar un anell, el podem trobar compartint una caixeta amb anells d'or, esmentat senzillament com a «unum crestayl». ${ }^{265} \mathrm{Ja}$ hem vist, en parlar de les armes, l'ús del cristall com a mànec d'una espasa - «ense»-preuada. ${ }^{2(6)}$ No hem d'oblidar que des del segle XIII es viu a Europa un creixement important en l'art del cristall treballat. ${ }^{267}$

Així mateix, també el vidre es pot convertir en un objecte luxós. Ja he indicat que en una bona cuina i en un bon rebost trobarem ampolles i àmfores de vidre, però

256 ACB, llibre notarial 8, fol. 57 v.

257 ACB, llibre notarial 9, fol. 13 r.

258 Vegeu nota 255.

259 Per exemple, ho veiem a ACB pergami 1-7-3014.

260 Ho veiem, per exemple, a ACB, llibre notarial 9. fol. 132 bis.

261 ACB, llibre notarial 9, fols. $134 \mathrm{i}$ ss.

262 IMHB Arxiu del Batlle $i$ el Veguer de Barcelona, X-1. fol. 4 v. - 6 r.

263 ACB, llibre notarial 9, fol. 131 bis v.

264 «Crestall és una pedre la qual ha aytall virtut que val contra sperits malignes e contra mal vents, e val que fa somiar e revelar sagrets amaguats. E si la sua pólvore és donada a beura ha nodrissa fa-li créxer e abundar la let. E aquesta pedra deu ésser encastada en fin argent, e deu ésser mesa sots la pedra una erba qui és apellada fonoyl» (Lapidari..., pàg. 6).

265 ACB, pergami 1-7-3014.

266 Ibidem. 339.

267 Joan Ramon Triadó I TUR, Cristall, Gran Enciclopèdia Catalana, VIII, Barcelona, 1987, pàg. 
uns altres cops veurem vidre especialment guardat com a objecte de luxe, com succeeix a casa de Jaume Cànoves, que té quatre gots de vidre de Damasc. ${ }^{268}$

Hem de parlar aquí també dels miralls. Sovint els veurem ben guardats $i$ ben guarnits: Domènec Olms en té dos, i un, guardat en una caixeta, és de coure «cum lapidibus vitreis" ${ }^{269}$ Unes altres vegades són veritablement senzills, se'ns indica que son de fusta, sens dubte referint-se al voltant de la part reflectant, i en algunes ocasions no se'ns en dóna cap detall. Per tant, no sempre és un objecte especialment luxós, si bé cal dir que la seva sola possessió ja deu ser important, sobretot si tenim present que n'hi ha pocs.

Així mateix, podríem esmentar ara les pintes. N'apareixen poques, i en les més riques de les cases resseguides en trobem dues. En el millor dels casos són daurades, o sia, amb un bany d'or, però també s'assoleix el luxe amb ivori, com la que té Bonanat Marí. ${ }^{270}$

Del treball d'ivori ja hem comentat que es sol emprar per a decorar mànecs de gavinets i caixetes i bústies. En el mateix sentit, cal observar com també s'utilitza, encara que menys que l'ivori, l'os com a recurs d'ostentació. Ja l'hem vist tant en mànecs de punxons com guarnint caixetes.

I també hem de recordar entre els guarniments luxosos l'ús dels teixits. El «dobblet lavorat» és ben clar, i ja hem repassat els treballs de seda i. la tria selectiva de teles.

Del guarniment dels mobles - pintar-los, fins i tot amb un escut- ja n'hem parlat en comentar les caixes. A més, per a decorar la llar, cal observar les accions destinades a cobrir les parets. A vegades trobarem, a la paret, els escuts del propietari de la casa. I en poques ocasions i sempre en cases riques, com la de Jaume Cànoves o la de Bonanat Marí, apreciarem un treball tèxtil de colors clavat a la paret, uuna storam pictam fixam perieti». ${ }^{271}$ No se'ns indica si es tracta de representacions figuratives en el sentit que ens seran conegudes un segle després, ${ }^{272}$ i no han de ser confoses amb una "aztora pintada de spart», que tot i ser «pintada» servia per a ser "posada en la intrada de la sala», a terra. ${ }^{273}$

En canvi, quan ens trobem un «reetaula», com ho veiem a casa de Pere Rovira, ${ }^{274}$ tant el context com la manca de detalls pictòrics, ens indiquen clarament que no l'hem de relacionar amb un «rera-taula» decorat sinó amb un «retauló».

Cal observar que un material com és la fusta també és susceptible de ser treballat amb finalitat decorativa. Ja hem vist la taula treballada amb «sculpturis»

268 ACB, llibre notarial 9, fol. $13 \mathrm{r}$.

269 ACB, pergami 1-7-3014.

270 ACB, llibre notarial 9, fol. $133 \mathrm{v}$

271 ACB, llibre notarial 9, fols. 12 r. i 134 r., respectivament.

272 Micer Vicenç Pedriça deixa, a la seva casa de Barcelona en morir el 1435, wun drap de paret de pinzell de la instoria de Hugerw (Otger Cataló) (Mn Joan SEGURA, Historia d'Igualada, II, (ed. facsímil), Igualada, 1978, pàg. 245).

273 Per exemple, la veiem a AHCT, Clavaria, llibre 23 (1386), pàg. 129.

274 ACB, llibre notarial 8, fol. 57 v.a: 
que té Bonanat Marí. Però també ens podem trobar peces concretes de fusta treballada, si bé molt escasses, com la peça de xiprer que trobem a casa de Jaume Cànoves. ${ }^{27 s}$.

Finalment, com d'un objecte d'ostentació relativament corrent, cal parlar de «les gabies de papagay». N'hi ha força. ${ }^{276}$ Són gàbies expresses per a tenir-hi papagai - "ad tenendum papagay»-. Però mai no hem vist el papagai, que, en canvi, trobem en els alts estaments de la societat. ${ }^{27}$ No hem d'identificar, però, papagai amb guacamai. En dir papagai es referien a qualsevol animal psitaciforme.

\section{Música}

D'objectes destinats exclusivament al lleure sols trobarem els instruments musicals. ${ }^{278}$ Trobem la cemba, -un tipus de tambor-, a casa de Domènec Olms, i a casa de Jaume Cànoves, que és més ric i se'ns mostra com un important mercader, hi veiem un llaüt i una guitarra. Quan el notari Vilarrúbies realitza l'inventari dels béns de Cànoves, els va escrivint cada un pel seu nom, però en l'arribar al llaüt diu "quodam instrumentum quod vocatur lahut», i fins $\mathrm{i}$ tot ha d'escriure dos cops el nom de l'instrument perquè s'equivoca, $i$ tot seguit farà el mateix circumloqui amb la guitarra, ${ }^{279}$ com palesant que es tracta d'objectes no gaire habituals. El cert és que la guitarra la trobem força abans del període -segles XV i XVI- que, segons Montserrat Albet, és molt difosa a les nostres terres. ${ }^{280} \mathrm{I}$ pel que fa al llaüt, si el creiem de les característiques que segons Michel tenen els llaüts en el temps i espai que estudiem, seria de quatre cordes i es tractaria d'un «laud cortopiriforme con puente en la base de la caja y con ésta muy abombada». ${ }^{281}$

\section{Objectes de devoció}

Els objectes amb una finalitat exclussivament devocional són ben rars i escadussers. Abans, entre els objectes luxosos, ja he parlat de l' «Agnus Dei» com a reliquiari

275 ACB, llibre notarial 9, fol. 12 r.

276 En podem veure, com a exemples ben clars, a $A C B$ pergamí 4-10-58 a i llibre notarial 9, fols. $13 \mathrm{v}$ i $133 \mathrm{v}$. $134 \mathrm{r}$.

277 Sabem que, dècades després, la reina Elionor, esposa de Pere III, «criava un rossinyol y un papagay» (Dra. Ulla Deibel, La Reyna Elionor de Sicilia, «Memorias de la Real Academia de las Buenas Letras de Barcelona», X (Sobiranes de Catalunya), Barcelona, 1928, pàg. 388, basant-se en ACA, registre 1811 fol. 73 v.). I dècades abans sabem que el futur Pere II també gaudia de la companyia d'un papagai (Joaquim MIRET I SANS, Viatges del infant en Pere, fill de Jaume I, «Butlletí del Centre Excursionista de Catalunyaw, XVIII, (1908), pàg. 178).

$278 \mathrm{Ja}$ en inventaris d'alguns anys abans es troben instruments (cítara, llaüts) entre burgesos de Barcelona: Carme BATLLE, La casa i els béns de Bermat Durfort, ciutadà de Barcelona, a la fí del segle XIII, «Acta Mediaevalia» IX (1988), pàg. 19 i nota 8.

279 ACB, llibre notarial 9, pàg. $14 \mathrm{r}$. 311 .

280 Montserrat Albet I Vilı, Guitarra, Gran Enciclopèdia Catalana, XII, Barcelona, 1987, pàg.

281 F. MICHEL, director, Enciclopedia Salvat de la Música, III, Barcelona, 1967, pàg. 159. 
recobert de plata amb l'anyell del Senyor marcat i que sols apareix en una ocasióo. ${ }^{282}$

També una sola vegada, a casa de Jaume Cànoves, ${ }^{281}$ veurem una petita quantitat de cera, quasi una lliura, desada entre objectes bons i preuats, la qual cosa fa pensar que es pot tractar de cera beneïda.

En altres inventaris no es registren objectes especialment devocionals.

\section{Il.luminació}

La il.luminació nocturna a les cases es fa mitjançant les candeles. Obviament n'hi ha a totes les cases, i n'hi ha moltes, comptades amb ròtols (per la seva forma cilíndrica, de «rotllos»). A casa de Domènec Olms el notari compta 28 candeles, per citar una xifra que comparativament no és pas gaire elevada. Totes les candeles que trobem citades són de cera, $i$ algunes especifiquen que són de cera blanca, mentre que en altres casos sols es diu que es tracta de "candelis albis». ${ }^{2 m}$

Les candeles que no s'usen es guarden dins la "candelaria», que és una caixa de fusta i normalment petita feta amb la finalitat de recollir les candeles. El cert és que de candelàries en veurem poques, com a molt una en cada casa rica.

Respecte a suports especials per a sostenir les candeles, no són gaire corrents. Només a les cases més riques trobem llanternes, llumaneres i canelobres.

Escasses vegades veurem canelobres: Jaume Cànoves, per exemple, n'arriba a tenir dos. ${ }^{2 s s}$ Tots els canelobres que coneixem o són de coure o de llautó. En canvi, les llumeneres, també ben escasses, són de ferro, a l'igual de les llanternes. ${ }^{286}$

Les llanternes s'empraven per a il.luminar-se en la foscor de les nits de les ciutats i viles medievals. L'obscuritat dels carrers era un costant perill, refugi permanent de gran diversitat de violències i excessos. Els consells municipals maldaran per controlar aquesta situació i si bé, quasi un segle després del període que ens ocupa, trobarem consells municipals com el de Tarragona que ordenaran «que tots los vespres tot hom tinga lums a les finestres", ${ }^{287}$ la mesura que sempre veurem emprar a tot arreu és el manament de no circular per la ciutat després de toc «del seny del ladre". ${ }^{219}$ Però el compliment d'aquesta mesura haurà de ser imposada cada nit pels oficials de justícia, que recorren els carrers precisament il.luminat-se amb llanter-

282 Vegeu nota 263.

283 ACB, llibre notarial 9, fol. $13 \mathrm{r}$.

284 L'alternativa a les candeles de cera són les de sèu (com ho veiem, quasi un segle més tard, a ACA, Mestre Racional 1528, fol. 239 r.), que no ens han aparegut en cap inventari.

285 ACB, llibre notarial 9, fol. 12 r

286 ACB, pergami 4-10-58 a i llibre notarial 8, 57 r., per citar dos exemples.

287 Ordinacions i crides de la ciutat de Tarragona (segles XIV-XVII), Tarragona, 1982, pàg. 43.

288 Per posar exemples allunyats sobre aquesta preocupació municipal respecte la seguretat i l'ordre a la nit, podem veure el cas de Tortosa (AHCT, Claveria 1336, pàg. 33 v. i Paheria i Vegueria I, fol. 39 r.) i el de Manresa (Joaquim SARret i ARBós. Història de l'estat político-social de Manresa, Manresa, 1925, pàg. 70). A Barcelona podem apreciar aquesta problemàtica clarament en les ordinacions municipals (vegeu el comentari que en fa Francisco-Luís CARDOna CASTRO, op. citada, pàg. 62). 
nes, ${ }^{2+4 y}$ de la mateixa manera que també les empren els autoritzats a circular per la ciutat de nit, com els qui visiten malalts o els qui han de fer-ho per raó del seu ofici. ${ }^{2 * 1}$

\section{Comptabilitat}

A casa d'alguns mercaders trobarem llibres per a portar els comptes - «liber papiri computorum" ${ }^{201}$ - $\mathrm{i}$ fins $\mathrm{i}$ tot veurem "cordoni cirici apti ad signum libri", com els tres que té Jaume Forn. ${ }^{292}$ També constatarem la presència de tinters, que són de fusta. ${ }^{2 \%}$

Cal dir que parlem d'objectes ben rars. Apareixen molt escadusserament. I és clar que un altre tipus de llibre és completament desconegut en el grup social en què ens movem. ${ }^{291}$

\section{Balances}

És relativament facil trobar balances. Sens dubte hem de relacionar-ho principalment amb les activitats comercials desenvolupades a Barcelona. Les que més es troben són de llautó, si bé no són gens estranyes les de coure, i en ambdós casos el calastó és de ferro. A dins de casa seva, no pas a les botigues, en Cànoves, per veure un exemple concret, té diverses balances, unes de coure i unes altres de llautó. Les que empra són les de llautó, $i$ les de coure les té ben desades dins d'una caixa. ${ }^{29}$

No totes les balances són de la mateixa mida, n'hi ha de grans i de petites, i fins i tot a vegades es parla de balancetes - «balancieta» ${ }^{2 \%}$ - . Tampoc no hem d'imaginarles completes, a vegades s'inventarien especificant que hi falta el calastó. ${ }^{297}$

A casa del mateix Cànoves trobem també una romana, amb piló i calastó. $\mathrm{La}$ romana, la veiem feta de ferro.

Per a pesar fan falta els pesos - "pesalia»-, que són de llautó o de coure i en el millor dels casos es guarden en una caixa "sive estoig" feta a propòsit. Sovint els podem trobar formant un conjunt amb la balança corresponent.

\section{Per a la bèstia}

No és estrany trobar l'equipament necessari per a la bèstia (denominació 153.

289 Veiem aquest ús de la llanterna, per exemple, a Tortosa, AHCT, Clavaria llibre 26 (1386), pàg.

290 IMHB, Fons Municipal B-I llibre de Consell Municipal núm. 9 (1326), fol. 10.

291 Expressió que podem veure, per exemple, a ACB, pergamí 1-7-3014.

292 ACB, pergami 1-7-3014.

293 ACB, llibre notarial 9, fol. 13 r.

294 En canvi, per les mateixes dades, trobarem, com és ben comprensible, llibres entre els béns d'un «savi en dretw (ACB, pergami 4-101-7; referència a Josep BAUCELLS, El Maresme i la Pía Almoina de la Sen de Barcelona. Inventari de pergamins, Barcelona, 1987. Pàgs. 141-142).

295 ACB, llibre notarial 9, fols. 12 v. - 13 r.

296 Veure nota anterior.

297 Per exemple, ho veiem a ACB, llibre notarial 9, fol. 12 r. 
genèrica que s'aplicava a tot cavall, mul o rossí). En primer lloc veurem la sella, el seient que es col.loca sobre la bèstia per tal de poder-hi cavalcar. La sella porta algunes vegades el «signum» del seu propietari. Pot passar, però, que el propietari perdi la sella i passi a propietat d'un altre tot $\mathrm{i}$ continuar tenint el "signum»: entre els béns que es trobaren a casa de Domènec Olms quan va morir, es va inventariar una sella "cum signo Nobilis Philipi de Saluciis». ${ }^{29}$

Totes les selles que hem trobat es posaven, quan no les portava l'animal, sobre un "cavayl fust». No cal que n'hi hagi un per a cada sella: Jaume Cànoves té quatre selles i ún sol "cavall fust». ${ }^{299}$

També trobarem el fre, que a vegades porta conjuntament les capçanes, que són el conjunt de corretges que subjecten el cap de la bèstia.

Algunes vegades veiem elements de càrrega, com la sàrria, que, seguint la definició de l'Alcover, ${ }^{300}$ hem d'imaginar com un recipient d'espart amb dues bosses, una per a cada costat del llom de l'animal, a fi de poder-lo carregar. ${ }^{301}$

S'inventaria més vegades tot aquest material que no pas la bèstia. I quan aquesta apareix és sempre un mul, com ho veiem en el cas de Bonanat Marí ${ }^{302} \mathrm{Hem}$ de pensar, per fer una comparació, que un oficial reial de la categoria del veguer també viatja damunt un mul o, com a molt, un rossí. ${ }^{303}$

\section{Altres objectes}

Existeix un conjunt d'estris, d'aplicació múltiple, que trobem amb relativa frequència. Podríem aquí començar parlant del martell, que, de totes maneres, no és a tot arreu i, com a xifra màxima, solem veure'n un per a cada casa. Encara més escasses són les tenalles, que sempre que han aparegut les hem trobades de ferro, a l'igual de les barrines. També apareixen tisores, si bé són més habituals a casa d'artesans que les necessiten per a treballar, com a casa de Pere Rovira, que és un capeller, de la mateixa manera que sols ell té "pertxes», pals llargs que serviran per a penjar-hi la mercaderia $i$ que veurem pintats de vermell i d'ensafranat. ${ }^{304}$

$\Lambda$ vegades trobem «secures». Aquesta mena de dalles, que les poques vegades que s'inventarien es situen a prop de la cuina, s'especifiquen en mida gran i petita. Jaume Cànoves, per exemple, en té una de cada, una de gran i una de petita. ${ }^{305}$ També constatem, encara en menys ocasions, algunes aixades amples ( «ligones»). Ja hem parlat abans del ganivet, al qual obviament hem de suposar un conjunt d'aplicacions ben ampli.

298 ACB, pergami 1-7-3014.

299 ACB, llibre notrial 9, fol. $14 \mathrm{r}$.

300 A. M. AlCOVER - F. B. MOLL, Diccionari català-valencià-balear, IX, Palma de Mallorca, 1969, pag. $760-761$.

301 Per exemple, en té el capeller Pere Rovira (ACB, llibre notarial 8, fol. 57 r.)

302 ACB, llibre notarial 9, fol. 132 v., una «mula de pilo rubeow.

303 Per exemple podem veure-ho a ACA, Mestre Racional 1527, fol. 296 r.

304 ACB, llibre notarial 8, fols. 56 r. i ss.

305 ACB, llibre notarial 9, fol. $14 \mathrm{r}$. 
També podem trobar alguna escala de fusta llarga ${ }^{300} \mathrm{i}$ més d'un cadenat de ferro amb la seva corresponent clau, encara que a vegades sigui rovellat. ${ }^{307}$

Un objecte força habitual és el ventall. Tots els que trobem els veiem de palma, i alguns són pintats, òbviament millors. Un ventall senzill pot tenir diferents funcions, però el ventall pintat és més delicat, i el trobem entre objectes preuats.

Relativament freqüents són els "ferrei putei», que ens parlen de l'obtenció d'aigua de pou. ${ }^{308}$

Finalment, cal esmentar les rateres de ferro. Apareixen ben poc, però per exemple n'hi ha una a casa de Bonanat Marí. ${ }^{309}$ No se'ns detalla com són, però la seva finalitat és ben evident, i segurament s'adreça més contra els ratolins que no pas contra les rates, tot $i$ trobar-nos en un moment en què encara continua l'amenaçant «explosion démographie» de la rata negra iniciada entre els segles XII i XIII. ${ }^{310}$

\section{Però No a TOTES Les CASES}

Efectivament, acabem de resseguir un grapat de cases de la Barcelona del començament del segle XIV $\mathrm{i}$ hem pogut resumir en diferents apartats els objectes que s'hi troben. Ja he advertit, abans d'iniciar el recorregut, que, evidentment, haviem de fugir de tot perill de generalització. Ara cal concretar més aquest aspecte.

És clar que hi ha molta diferència entre els béns que trobem en unes o en altres cases. Existeix en primer lloc un factor econòmic. En els inventaris de gent rica ens apareixen, per començar, més caixes i més arquibancs (la gent amb menys poder econòmic no ens mostra gaires arquibancs). Semblant apreciació hem de fer de la resta del mobiliari: d'escons i de taules rodones, es pot dir que sols en trobarem en una casa rica. Però aquest matís econòmic determina no solament la quantitat dels objectes que es posseeixen, sinó fins i tot l'existència mateixa d'aquests objectes. Hi ha estris que gairebé tan sols els trobarem en una casa rica. És el cas dels recipients metàl.lics (barralets, flascons, bacins) o de les peces de l'armadura.

Cal observar la incidència d'aquest factor econòmic sobre els materials dels estris. Els objectes metàl.lics els anirem trobant en relació amb el poder adquisitiu. Ara bé, això no vol dir que la gent més pobra -almenys fins al grau que es pot reflectir en els inventaris- substitueixi els estris metàl.lics per uns altres de fets amb materials més pobres, com la fusta o la terrissa. Així, en objectes que encara que útils no són imprescindibles, com els esmentats recipients o les armes, o es tenen fets dels metalls que abans hem vist o senzillament no es tenen. I en objectes que són

306 ACB, llibre notarial 9, fol. $14 \mathrm{r}$.

307 ACB, pergamí 1-7-3014.

308 ACB, llibre notarial 9, fol. 14r. i 132v., per exemple.

309 ACB, llibre notarial 9, $125 \mathrm{v}$.

310 Robert DELORT, Les animaux en Occident du Xè au XVIè siècle», a "Le monde animal et ses representations an Moyen-Age (XIè-XVè siècles), «Actes du XVème Congrès de la Société des Historiens Médiévistes de l'Enseignement Supérieur Public, Toulouse, 1984", (Université de Toulouse-Le Mirail, 1985). Pàgs. 37-38. 
imprescindibles, com els estris necessaris per a cuinar, no trobarem ningú que substitueixi els estris metàl.lics per uns altres de terrissa, per exemple, sinó que si de cas se'n tindran en menor nombre." El material dels objectes s'aprecia bastant fix: hem vist com tothom té escudelles de fusta i sols en algun cas, com a casa de Jaume Cànoves, en veiem d'estany, però si ens hi fixem bé, veurem que Cànoves té aquestes escudelles metàl liques desades al costat dels coberts de plata, i a la cuina hi té, com tothom, escudelles de fusta, amb la diferència que en té moltes més que la resta de gent coneguda."

En altres casos, com el de la roba, sí que hi constarem una diferència qualitativa. A les millors cases trobarem coixins farcits de plomes, i sobretúniques amb llenques de pell i fins i tot amb botons d'argent, i les robes es van succeint des de l'estopa al lli, materials que trobem comunament, i segueixen amb les teles més preuades.

Potser cal que ens aturem en la seda. Hem d'observar tant la seva gran abundància habitual com les seves possibilitats. En trobarem a tot arreu, i no és res d'especial: molt sovint veiem objectes de seda considerats d'ínfim valor, com «duo cuxini partim operati de ciricon que té Domènec Olms i que el notari Pere Colomer descriu com a "veteri et modice valoris»." $L$ 'ús de la seda és molt ampli, des dels cordons dels capells de sol $\mathrm{i}$ dels llibres al sedàs. I té una capacitat guarnidora ben clara, que copsem, sobretot, en l'expressió corrent i resumida que ens indica que és "treballat de seda".

Evidentment, on més es notaran les diferències econòmiques és en els objectes merament sumptuaris. I ja he indicat que en aquest aspecte també hi ha una gradació, que comença, quant a facilitat i desig d'adquisició, per les copes d'argent, les culleres de plata $i$ els anells d'or.

Fixem-nos que en el fet de trobar més copes que no pas tasses de plata, sense voler simplificar en excés, podem apreciar-hi la participació de factors potser no solament econòmics. I és que no hem de caure en un miratge excessiu respecte al factor econòmic. No hem de pensar que pel fet de ser ric es té més $i$ millor de tot. Aturem-nos en el calçat o en la roba, on hi ha peces que escassegen força o senzillament sols s'inventarien entre els rics, com és el cas de tot el que podríem anomenar roba interior (trabugueres, quadrells, camises, sobretot el farcet). En aquests casos s'aprecia facilment que la diferència bàsica entre la roba dels més rics i els que ho són menys segons els inventaris, no la veurem precisament en el seu nombre: l'inventari ens reflecteix que Jaume Cànoves és més ric que no pas Domènec Olms, però no per això Cànoves té moltes més clàmides que aquest, $\mathrm{i}$ de sobretúniques només en té dues i de túniques tres. La gent rica mostra, doncs, més varietat de roba, i la té més guarnida, però no en té gaire més.

En la roba de la llar podem fer raonaments semblants. Com més rics, això sí,

311 A una conclusió semblant arribà l'estudi de l'Equip Broida centrat en l'ús de la terrissa a la Barcelona cent anys posterior a la que ara analitzem (Equip BROIDA. Els atuells de terrissa a les llars barcelonines vers l'any 1400, a Manuel RIU, dir. Ceràmica grisa i terrissa popular de la Catalunya medieval, «Acta Mediaevalia, annexos d'arqueologia medieval» II, (1983-1984), pàgs. 199-239.

312 ACB, llibre notarial 9, fols.12 r. i ss.

313 ACB, pergamí 1-7-3014. 
més llençols es tenen -també més llits o taulons convertibles en llits- i també més cobertors, i molta varietat de roba sols la trobarem, i encara escassament representa$\mathrm{da}$, entre gent rica. Però, en canvi, en altres robes no hi ha gaires diferències -a part de la tria a vegades de millors teles o millors guarniments-, senzillament perquè no es vol, perquè no s'hi veu la necessitat. Jaume Cànoves, per continuar amb el mateix exemple de persona rica, no té gaires flassades i, pel que fa als draps per a la llar, comparat amb els que demostren ser més pobres que ell, té un nombre similar de tovallons (tots en solen posseir entre deu i vint), tovalloles (tothom en té entre una $i$ cinc) o estovalles (tots en tenen una o dues $i$ ell en té tres).

El factor econòmic cal també conjuminar-lo amb uns altres de culturals o de gust. Ho veiem potser en els instruments musicals. A les cases no riques, és clar, no en trobem, però podem apreciar que Bonanat Marí se'ns mostra més ric que Jaume Cànoves i molt més que Domènec Olms i, en canvi, ell no té cap instrument musical i aquests dos si que en tenen.

També podem esmentar els salers. Són raríssims, i els trobem en algunes cases poderoses, però Cànoves, que és molt ric, no en té. $O$, per exemple, la salsera. És feta amb un material pobre, terrissa, i en canvi en trobarem en molt poques cases: el seu ús no és imprescindible.

Podem continuar el raonament amb els còmputs lunars. En trobem a la majoria de les cases, però, en canvi, no en veiem a casa de Jaume Cànoves, el qual, a més, sabem que era comerciant. Segurament, però, ell ja podia tenir qui li ho podia calcular sense haver-ho de fer ell mateix.

I tot parlant de gustos i atraccions, potser hauríem de fer esment de l'interès pels models foranis que sempre (tan sols llevat dels barrets de sol castellans, que trobem al ja esmentat obrador de capeller) miren a les terres properes per l'est i a les terres musulmanes: tovalloles gàl.liques, manutèrgies franceses, capes alemanyes, llençols de Sicília, sàvena sarracènica, barrets alemanys i sicilians... com podem veure tot centrat en la roba, encara que també tenim la caixa, el bacinet i la braçerola pisanes.

Un altre detall a tenir també present és l'afany per a conservar tots els estris i fragments. Per descomptat que ho trobem en joies -fragments de plata, per exemple-, però també ho apreciarem en els estris de cuina: veurem conservar conques $i$ calderes trencades, fins $i$ tot a les cases més riques, ${ }^{314} \mathrm{i}$ en moltes cases trobarem desades peces de l'armadura en mal estat, com una «cuxeriam ferream ruginatam"," 0 armes corcades ${ }^{316}$ o fins $i$ tot caixetes sense fons $i$ cadires sense seient. Certament, s'observa amb claredat que pràcticament no es desaprofitava res. De totes maneres, tot $\mathrm{i}$ ser una dada important, no podem portar als extrems el raonament sobre una duresa econòmica en el nivell de vida a partir del que ens diuen els inventaris. Em refereixo a la possibilitat que en aquest aspecte alguns inventaris puguin ésser viciats per la voluntat de marcar les coses amb un valor baix: el notari de la cort del veguer, Pere de Colomer, autoritza l'inventari dels béns de Domènec Olms el dia 9 d'agost de 1309 a petició del germà del difunt, que és curador dels béns

314 ACB, llibre notarial 9, fol. 14 r., per exemple.

315 ACB, pergamí 1-7-3014.

316 qquandam clavam cum manubrio nervorum picto corrosew (ACB, llibre notarial 9, fol. 13 r.). 
del mort, béns que hauran de rebre els fills del difunt quan tinguin suficient edat. Curiosament -o sospitosament- el notari és capaç d'omplir 41 ratlles d'un considerable pergamí citant tots els objectes i sabent col.locar a continuació gairebé de cada objecte un sinònim de "modici valoris»."1

Un altre factor que cal tenir present és la dificultat de fer càlculs globals a nivell familiar. No tots els béns d'una casa són del propietari. Així, per exemple, en fer el recompte dels béns de Jaume Cànoves, s'ha d'especificar que «unam botam magnam» que té al seu celler pertany en realitat de la seva filla. ${ }^{318}$ Però normalment no és sols un detallet, com aquest exemple posat. Sovint es diferencien els béns del marit i de l'esposa, i solament trobem relacionada aleshores una part dels béns de la llar. Podem observar com la dona sol tenir com a propietat seva, sobretot, la majoria de la roba del llit $i$, després $i$ en diferents mesures, joies i guarniments i gran part de la seva roba de vestir. ${ }^{319}$

\author{
FLOCEL SABATÉ \\ Institut de Batxilerat \\ Pere Vives Vich. Igualada
}

(Barcelona)

317 ACB, pergamí 1-7-3014.

318 ACB, llibre notarial 9 , fol. $14 \mathrm{v}$.

319 Podem veure, per exemple, l'inventari amb els béns que deixa Maria, esposa de Guillem Pere d'Esplugues, en morir (ACB, pergamí 1-7-2551); o, encara molt més precís i breu, l'inventari dels béns que foren de Margarida, que fou esposa de Berenguer Adarrone (ACB, llibre notarial 8, fol. $6 r$.). 


\begin{abstract}
APENDIX
Afegir al text presentat un apèndix documental, crec que en aquest treball és gairebé obligat, atès el caire constantment comparatiu i complementari amb què ha calgut abordar l'estudi. Però, dissortadament, contemplar aquí tota la documentació emprada en la confecció d'aquest treball desbordaria les previsions d'espai. Per això cal fer una selecció, tot i coneixent els problemes que aquesta pretensió comporta (sempre hi haurà aspectes més ben representats en un inventari o altre, i sempre cal deixar d'exposar textos que semblen importants).

Abans d'endinsar-nos en la lectura dels documents oferts en aquest apèndix, cal encara fer més puntualitzacions. Cal tenir present la naturalesa del material documental emprat, els inventaris. Hem de pensar que la finalitat dels inventaris no era altra que fer un llistat de tots els béns $i$ propietats d'un difunt. Per aquesta raó, en els inventaris hi trobarem instruments de deute, propietats, comandes, mercaderies diverses segons els negocis, relació d'esclaus... tot un conjunt d'elements que converteixen la documentació en molt rica $i$ fins $i$ tot suggeridora, però que per a nosaltres, que hem centrat l'estudi en els objectes de la llar, són una munió d'objectes que ara no podem abordar. És per aquesta raó que la mostra documental oferta és fragmentària, centrada en el tema d'estudi plantejat fins aquí, les llars barcelonines en començar el segle XIV, i oblidant els fragments que ens trameten altres informacions.

Finalment, cal precisar una sèrie de signes emprats:

[...] engloba les parts que no es poden llegir perquè s'ha malmès el paper o pergamí des de la seva redacció fins ara.

.../... significa els fragments que no es transcriuen perquè no interessen en la present transcripció fragmentària.

$1 /$ indica les parts del text que el redactor ha intercalat.
\end{abstract}

1302, desembre, 4. Barcelona.

Inventari que Guillem Pere d'Esplugues fa realitzar dels béns de la que fou la seva esposa, Maria, filla de Bernat Faylibe i de Bruneta, esposa d'aquest. ${ }^{320}$ Notari, Bernat de Vilarribia.

320 El pergamí 14.004 de l'Arxiu Parroquial de Santa Maria del Mar ens aporta dades sobre el matrimoni Bernat Faylibe i Bruneta, mostrant-nos una venda dels seus drets sobre 5 cases, realitzada a Barcelona el 7 de gener de 1306. En l'inventari dels pergamins de l'Arxiu de Santa Maria del Mar 
Arxiu Capitular de Barcelona, pergami 1-7-2551.

In Dei nomine Ego Guillemus Petri de Speluncis draperius civis Barchinone heresque universalis domine Marie quondam uxoris mee filieque Bernardi Faylibe civis eiusdem civitatis cuius domine Marie quondam uxoris mee corpus die proxime preterita fuit traditum sepulture cum hoc venerabili signo + facio inventarium seu repertorium de bonis que inveni in hereditate dicte [...] mee quondam. Primum inveni dotem quam ipsa uxor mea michi apportavit tempore nupciarum nostrarum, que dos est quinque milium solidorum monete barchinone de terno prout per instrumentum inde factum $[\ldots]$ hereditate supellectilia sive res subscriptas quas eadem domina uxor mea quondam habebat in suis parafernis post contractum matrimonium inter me et eam. Que res predicte sunt et $[. .$.$] in hospicio quod ego et ipsa uxor mea quondam inhabitabamus. Que quidem$ res sunt hee videlicet duo matalafia quorum alterum est novum et alterum vetus. Item quedam strelenca listata et quedam flac[...] quoddam transverserium et tria capcialia vetera et quoddam matalafium ruptum veterrimum et modici valoris aptum serventi, et duo sedilia de colore nigro et croceo. Item quedam caxia magna cum pedibus coloris viridis in cohopertorio eiusdem et in anteriori parte sunt duo scuta. Item quedam caxiuncula picta. Item quoddam orale de perlis veris. Item quidam affibblays de canonis argenti aptis clamidi domine, quos affibblays dictus Bernardus Faylibe et domina Bruneta uxor sua dederunt dicte uxori mee quondam filie eorum, pro quibus quidem affibblays ego habui dare de meo dicte domine Brunete ad opus sue clamidis quosdam alios affibblays de cirico violaceo cum botonis in qua quidem clamide dicti affibblays argenti erant. Item quoddam cohopertorium cum barris de panno lini albis et cum barris sendati virmilii. Item quoddam cohopertorium vetus cum punctis croceis et virmiliis et quoddam tapetum vetus et quedam vanova alba parva et vetus. Hec [...] dicta sunt et non alia inveni in hereditate predicta, protestans quod si de cetero invenero aliqua alia bona in ipsa hereditate mox faciam inventarium de eisdem. Actum est hoc pridie nonas decembris anno domini Millesimo Trecentesimo Secundo. Sig+num Guillemi Petri de Speluncis predicti qui hec laudo, concedo et firmo. Testes huius rei sunt Bernardus de Speluncis, Jacobus Baboti et Petrus de Serra. Sig+num Bernardi de Villarubia notarii publici barchinone qui hec scribi fecit et clausit cum litteris appositis in linea tercia ubi scribitur inveni.

1303, agost, 9. Barcelona

Inventari dels béns de Domènec d'Olm, realizzat a petició de Pasqual d'Olm, germà del difunt i curador dels seus béns. Notari, Pere de Colomer.

Arxiu Capitular de Barcelona, pergamí 1-7-3014.

Cum propter doli maculam evitandam omnisque fraudis suspicionem tollendam et ut bona eorum qui sub tutela vel cura sunt ocultari non valeant vel lapsu temporis deperire, tutores et curatores postquam sunt constituti teneantur facere inventarium seu repertorium de bonis que reperiuntur in hereditate eorum quorum tutelam curam sive aministracionem suscipiunt. Idcirco, ego Paschalis de

(Manuel RIU i Joan PINTÓ, La documentación de la primera mitad del siglo XIV conservada en el Archivo de la Basilica de Santa Maria del Mar (Barcelona), a M. RuU dir., La pobreza y la asistencia a los pobres en la Cataluña medieval, I, Barcelona 1980), s'apunta la possibilitat que el cognom Faylibe equivalgués a Fivaller. Aquesta possibilitat sembla, però, quedar descartada quan podem comprovar com coexisteixen, el 1308, ben diferenciats i sense confondre's un Faylibe i un Fiveller: ACB, llibre notarial 9, 129v i 130v. 
Ulmo civis Barchinone filius Petri de Ulmo quondam curator per venerabilem Guillemum de Castroveteri tunc vicarium Barchinone et Vallensis datus constitutus et assignatus bonis et iuribus Dominici de Ulmo fratris mei cum publico instrumento per alphabetum diviso facto auctoritate Bernardi de Cumbis notarii publici Barchinone regentisque scribaniam Curie vicarii eiusdem civitatis undecimo kalendas septembris anno Domini Millesimo Trecentesimo Secundo, attendens me fecisse inventarium mox quam potui de bonis et juribus dicti ffratris mei cum publico instrumento inde confecto auctoritate Bernardi de Villarubia notarii Barchinone quarto idus septembris anno domini Millesimo CCC Secundo, in quo inter alia continetur me intellexisse quod in bonis dicti Dominici sunt quedam caxie in quibus sunt alique res ut intellexi numerum quarum caxiarum et qualitatem seu quantitatem earundem rerum non intellexeram licet super hoc fecissem posse meum, que caxie cum rebus in eis contentis erant in posse domine Valençe uxoris Bernardi de Fontecohoperto notarii quondam de quibus quidem caxiis et rebus predictis dicta domina Valença dicebat se habere retraccione pro quibusdam que asserit sibi deberi per dictum Dominicum; attendens etiam quod ego protestatus fui in dicto inventario quod si de cetero invenirem alia bona dicti Dominici mox facerem tam de ipsis bonis quod de predictis caxiis et rebus ibi contentis cum inde certificatus essem et michi constaret inventarium seu repertorium; attendensque me composuisse cum dicta Valença super dictis caxiis et rebus quas a dicto Dominico tenebat et easdem ipsam michi tradidisse sub forma et condicionibus contentis in quodam publico instrumento inde confecto auctoritate subscripti notarii octavo idus augusti anno infrascripto. Idcirco ego dictus Paschalis volens et cupiens ut teneor satisfacere dicte cure et dictis et protestatis per me in dicto inventario, in nomine sancte et individue trinitatis patris et filii et spiritus sancti ac venerabili signo cru+cis vivifice hic a me imposito inventarium seu repertorium facio de dictis caxiis et aliis rebus et bonis dicti Dominici que penes dictam dominam erant quas michi tradidit. Primum habui et recepi a dicta Domina Valença quandam caxiam pisanescam in qua erant res que sequntur videlicet unus tabach et quedam scudella picta et duo cuxini partim operati de cirico veteri et modice valoris, item tria manutergia francisca in pecia, item quidam manille, item unum par linteaminum quatuor palmorum cum randa, item quidem pannus lini, item quoddam linteamen Sicilie listatum modice valoris, item quedam mape, item quedam pelvim de lautono, item duo capelli ffrancisci, alter de cirico et alter de lino. item duo marsupia operata vetera, item quoddam speculum fustrum, item quedam caxieta cum duobus cloqueariis argenteis, item due corrigie lane sine guarnimento, item quedam bena de sagnare, item duo paria d.affiblays de cirico veteri, item duodecim palmi de sindone crocea, item unum par trabugeriarum de cirico livido et quidam cordonus de cirico, item unus tros de trena aurea veteri. Item quadam alia caxeta cum quodam speculo de cupro et cum lapidibus vitreis e cum aliis fraschis minime valoris. Item quedam bustia picta cum duobus manecs ossi. Item quedam capsia cum clausura in qua erat quidam anulus auri cum saffilo, item duo anuli fracti auri alter cum saffilo et alter cum turchesia. Item unum crestayl. Item argentum fractum ponderatis duodecim denariorum minutorum. Item duodecim botoni de crestayl. Item quoddam sigillum cum signo ulmi. Item due fivelle de lautono. Item quoddam linteamen d.estopa ruptum. Item quidam liber papiri computorum. Item quedam instrumenta continentia capcionem quam Jacobus de Sancto Clemente fecit de dicto Dominico dum dictus Jacobus erat baiulus. Item unum ferre de massa de cupro modice valoris. Item unum compotum lune in quo sunt due rote fustee. Item tres trocii de sindone rubea veteri. Item quatuor pilei lini veteri. Item unum punxor cum manec d.os. Item tres fivelle de cupro viles. Item unum cadenat de ferro ruginato cum clave. Item in eadem caxia erat quidam caxonus cum clausura quem aperiri feci sine clave et erant ibi duo paria cirothecarum planarum et tres cordoni cirici apti ad signum libri. Item quadam tovayola cabada de cirico. Item viginti sex candele cere albe. Item unum capell d.almugaver fili nigri. Item duo entrementoria fustea cum vaginis. Item quoddam manutergium. Item .../...

Item quandam caxiam in qua inveni res que sequntur primum quasdam cembes, item tres fustes de broquers, item duo cercles de ferro de broquers, item unum broquerium modici valoris. Item quemdam gladium sive puam modici valoris, item quandam cuxeriam ferream ruginatam vilem, item quasdam alias fraschas modici valoris. Item quandam aliam caxiam in qua inveni hec que sequntur scilicet unum capellum d.armar, item quandam camisiam de guarnir. Item extra dictam 
caxiam quasdam perpuntes equi de sindone rubea vilissimas. Item quasdam bonetos viles. Item quoddam cohopertorium panni veteris et non magni valoris. Item quandam clamidem de saya tinta in grana cum pena vayre et cum uno pari taxillorum in quibus erant incastate sive enfilate tres uncie minus medio argencio perlarum verarum minutarum et viridarum quas ego vendidi per manus Juceffi Bonihominis judei cursoris Barchinone publici Sibilie uxori Berengarii Ermengaudi pictoris civis Barchinone precio septem librarum et quatuordecim solidorum ad rationem quinquaginta duorum solidorum pro qualibet uncia ut continetur in quodam publico instrumento inde confecto in posse subscripti notarii nonas augusti anno subscripto et de quo precio ego misi et posui in posse domine Valençe neptis mee septem libras ut continetur in quodam alio publico instrumento inde confecto in posse subscripti notarii VIII idus augusti anno infrascripto, item quandam cotam vilem cum capucio coloris de fetge cum pena vili cirogrillorum, item quandam clamidem listatam, item quandam tunicam mextadadam, item quandam clamidem et quoddam supertunicale scotatum de panno trocato cum sindone crocea. Item quoddam cohopertorium fustanni listati, item quoddam cohopertorium cohopertum de panno rubeo lini, item quoddam morterium de cupro parvum cum manu. Item quodddam trocium panni listati per força qui sunt quatuor palmi vel circa. Item quatuor cane stamenie rubee. Item unum perpunt de sindone rubea cum capello, item quasdam cuxerias, item unum capellum jubat de panno albo. Item quandam caxiam in qua inveni res que sequntur, primum quandam frenum cum capsanes et quandam sellam cum signo Nobilis Philipi de Saluciis. Item duos alquinces sive barregatos albos cum quibusdam listis. Item duos trocios panni stope listatos. Item quandam ferreriam, item quendam guant cum gorgeria de mayla. Item quandam aliam caxiam vacuam parvam. Item tres clipeos, item quandam bassegiam et duo paria d.esperdenyes et unum martellum, item quandam daracham corii, item duas darachas fusteas. Item duas ballistas de duobus pedibus et unam d.estrep et quandam aliam ballistam duorum pedum fractam. Item quosdam perpuntes de sindone rubea viles, item quasdam bonetes de panno bruno et modice valoris. Item unum broquerium et quandam maciam. Hec itaque omnia et singula et non alia inveni et confiteor me invenisse in bonis et juribus dicti Dominici de Ulmo prout superius continetur protestans quod si decetero invenero alia bona dicti Dominici mox faciam de ipsis bonis inventarium seu repertorium. Actum est hoc quinto idus augusti anno domini Millesimo Trecentesimo Tercio sig +num Paschalis de Ulmo predicti qui hec laudo et firmo. Testes huius rei sunt Jacobus de Cumbaherema et Nicholaus Petroni, scriptoris. Sig +num Petri de Columbario notarii publici Barchinone qui hec scribi fecit et clausit (.../...).

1306, agost, 30. Barcelona

Inventari dels béns de Jaume Forn, mercader mort a "Romania" (Imperi Bizanti) fet pels administradors de la Pia Almoina de la sex de Barcelona, a qui pertoca l'berincia. Trasllat de 1309.

Arxiu Capitular de Barcelona, pergami 4-10-58 a.

Hoc est translatum sumptum fideliter a quodam inventario cuius tenor talis est: In nomine domini nostri lesu Xristi amen, quod nos Gaucerandus de Barbarano et Raimundus de Vilalta canonici barchinone procuratores et amministratores elemosine sedis barchinone, heredis institute a Jacobo de Furno quondam qui decessit in partibus Romanie volentes non inconsulte set cum benefficio inventarii hereditati ipsius nos immiscere ne dicta elemosina vel nos ipsius nomine ultra vires tenamur et ut benefficium de iure debitum ex hoc inventario nobis et dicte elemosine integriter reservetur. In presencia notarii et testium infrascriptorum et in presencia etiam domine Sanccie uxoris dicti Jacobi de Furno quondam cum hoc venerabili signaculo sancte crucis + a nobis corporaliter hic imposito e impresso nomine dicte elemosine inventarium de omnibus bonis et rebus que in dicta hereditate invenimus .../... 
Item invenimus quandam magnam caxiam cum pedibus in qua invenimus quoddam auriculare operatum ex ambabus partibus operibus siricis cum flochs de sirico, quoddam cohopertorium vetus de sindone regali. Item quandam aliam caxiam magnam in qua invenimus quatuor cuxinos operatos de sirico e duos rotols de candelis albis, item quatuor paria socularium deauratorum mulieris et unum rotol de candelis et quoddam mandile novum. Item invenimus quandam aliam caxiam in qua invenimus usque ad mediam rovam de lino Alexandrie. Item invenimus quoddam archibanchum de tribus casis in quarum altera erat usque ad unum quartonum de lino, et in alia erant duo paria linteaminum de stopa et quatuor manutergia et quedam camisia hominis cum corda de sirico et quedam tovallie de stopa, et quedam tabule fustee de compoto, et in alia erant frasche viles et modicis valoris. Item invenimus duas tovallias et mediam duodeciam manutergiorum et duo paria linteaminum de lino quinque palmorum. Item quinque matalaffia et unam culçitram et tres travesserios et quoddam pulvinar et quandam vanovam veteram et aliam vanovam novam e tres recoldedors et unam cohopertam de plega et unum par linteaminum et quoddam cohopertorium de bort d.Alexandria et quondam marfagam sive sacrilectum et unam curtinam. Item duos cofres in quorum altero invenimus unam corrigiam strictam de sirico munitam de argento, et unum par linteaminum et unum linteamen et quasdam mappas et unum rotol de candelis et unam tovaylolam operatam de sirico et octo manutergia et unam soqueniam et quoddam mandile et unam cohopertam de travesserio et quosdam pectines deauratos et quandam cohopertam speculi et quandam caxietam modicam de osse in qua erat unus ganivet parvus de argento, et quandam capciola de ebore in qua erant tres annuli auri, in duobus quorum sunt lapides vocati safirs parvuli et in alio est quedam perla. Item in alio cofre erant quatuor capcie de cunfits vacue. Item invenimus quandam caxieta in qua invenimus tres savenas de sirico e quandam savenam sarracenicam de lino, et quoddam speculum, et unum salerio de stagno et unum bacinum parvum de ere et duas albanechas operatas de sirico. Item invenimus quandam atahut vetus et unam caxiam plenam de quadrellis. Item quandam lanternam de ferro et quandam tapete vile. Item quandam mensam magnam e tres banchos et unum cavayl fust. Item quandam gabiam de papagay et unum sacrilectum et duas flaciatas. Item unam concham et duas calderias, unam magnam et unam parvam. Item duas patellas et quosdam grahellas et duas locias et duos asters et unum morterium de cupro et unum ciffum de argento et unam taceam de argento quem et quam dicta domina dixit quod tenebat pigneratos quidam collector questie. Hec et non alia in hereditate predicta invenimus protestans quod si plura bona de cetero ad predictam hereditatem pertinenciam ad noticiam nostram pervenirent ea palam manifestabimus et de ipsis inventarium per publicum fieri faciemus prout de iure fuerit faciendum. Quod inventarium fuit incohatum tercio kalendas augusti anno domini Millesimo CCC Sexto presentibus testibus Bernardo de Turri, Ffrancisco de Piraria e Petro Geraldi .../...

4

1308, del 27 de setembre a l'1 d'octubre. Barcelona

Inventari dels béns de Jaume de Cànoves, fet per la seva filla i hereva Elisenda, vidua de Bernat de Puig.

Arxiu Capitular de Barcelona, llibre notarial núm. 9 (notari Bernat de Vilarrúbies), 12 r. - 16 r.

In dei nomine ego, Elisendis uxor Bernardi de Podio quondam filiaque Jacme de Canovis quondam $[. .$.$] eiusdem heresque universalis instituta a dicto patre meo quondam volens [...] consilium$ sacratissimi principis Justiniani eiusque beneficio uti quod heredibus inventarium faci [...] est concessum cum hoc venerabili signo crucis + die veneris qui est $\mathrm{V}$ kalendas octobris anno $\mathrm{M}$ CCC VIII. Qua die corpus dicti patris mei fuit traditum sepulture presens inventarium [...] in hereditate dicti patris mei quondam facere incepi. Primum inveni in dicta hereditate [...] caxiam scilicet fusteam in qua inveni III milia D LX VII carlinos argenti, item in eadem [...] turonençes argenti. Item inveni aliam caxiam in qua inveni quatuor milia denariorum argenti [...], item mille nongentos $\mathrm{L}$ 
VI turonenses argenti. Item inveni aliam caxiam scilicet fusteam in qua inveni $\mathrm{CC}[\ldots .$.$] pecias bisantio-$ rum auri veteram de Alexandria, item XI III florenos auri, item $L$ augustales auri, item VIII [...] auri mirias, item quatuor milia turonenses argenti, item mille CCC LXXV barchinonenses argenti, item septem[...] IX carlinos argenti, item XL libras in denariis barchinone minutis. .../...

Item inveni quoddam archibanche scilicet fustem, item inveni quandam caxiam scilicet fusteam in qua inveni VI mille turonenses argenti inter duos saccos. Item inveni VII mathalafia e II sitis, item IIII linteamina de lino vetera et vilia et I linteamen de stupa. Item quandam vanovam albam et unum cohopertorium de burdo de Alexandria et aliud coopertorium vetus de burdo de Barchinona, item unam culcitram de plumis e unum barraganum listatum, item duo linteamina quorum unum est vetus et vile, item duo traverserio cum plumis et unum cuxinum ipsarum, item quandam curtinam et II scuta, item II candelabra parva de cupro et IIII flascones de stanno et unam balistam de cornu veterem de strepo et unam massam armandi cum manubrio picto. Item quoddam marfanum fixum perieti. Item quandam cetram de lautono et unum frenum et unum par calcarium e unum conservatorium de corio ad opus ciphi argenti. Item quandam romanam de ferro cum suo pilono de ferre et unum calestonum de ferro et I seti de panno croceo et virmilio. Item quandam storam pictam fixam perieti. Item I tapetum vetus, item I recoudador de corio veterem, item I ensem cum pomo de cristallo et unum calastonum de ferro, item I camissollum de ferre et I cirothecam de ferro et quasdam balancias de cupro sine calestonem. Item II linteamina quorum alterum est vetus et ruptum, item quasdam tovallias et unam candaleriam parvam scilicet fusteam. Item quandam caxiam strictam et longam cum quibusdam cayrellis. Item II crocos sine manibus. Item invenimus quandam caxiam scilicet fusteam in qua inveni quoddam cohopertorium de scindone virmilia et VI coria de recoudadors e II scutellas de fuste pictas. Item unam peciam de dobblet levorat. Item [...] manus ventilabrorum pictorum de palma. Item I manile novum ad opus barbe et II purpuras et I pannum de cirico e[...] quasdam tovallias gallicas et IIII tovallionos. Item unam peciam de levorat de cipro. Item unam tovalliola operata cum cirico. Item unum trocium de panno cirici de Alexandria ad opus brisaldi, item I [...] de fuste operatum cum ossibus et unam coopertam de cuxino operatam cum cirico et unum ciphum de argento marcatum barchinone, item alium ciphum de argento marchatum barchinone, item alium ciphum de argento marchatum barchinone, item alium ciphum de argento marchatum barchinone, item alium ciphum de argento marcatum ad signum Janue et alium ciphum de argento cum quibusdam emprentes de signis florum marcatum barchinone, item alium ciphum argento marcatum janue. Item III tacias de argento. Item quasdam balancias parvas de cupro et IIII cloquearia de argento et XIIII anulos de auro cum quibusdam lapillis ibi insertis quorum nullus est magni valoris. Item $\mathbf{X}$ rotols de candelis de cera. Item III libras de gariofilo in uno saculo. Item alium ciphum de argento quem Johannes Alegre prepositus mensis aprilis tenet pigneri ratione peticionum quas movebat contra dominum Jacme de Canovis ratione cuiusdam honoris quem ipse Jacme emerat et qui tenetur per ipsam preposituram. Item inveni in quadam butiga unum saccum de cotono ponderantem cum sua sarpayeria IX arrovas et mediam, item aliam saccum de cotono ponderantem cum sua sarpayeria $\mathrm{X}$ arrovas et II libras, item unum saccum piperis ponderantem cum sua sarpayeria XII rovas et III libras, item alium saccum piperis ponderantem cum sua sarpayeria IX rovas et VII libras, item alium saccum piperis ponderantem cum sua sarpayeria IX rovas et VI libras, item alium saccum piperis ponderantem cum sua sarpayeria XIIII rovas et XI libras, item alium saccum piperis cum sua sarpayeria ponderantem XII rovas et XXII libras, item unum saccum de lacha de Erminia ponderantem cum sua sarpayeria IX rovas et mediam. Item quandam sportam de canella ponderantem incameratam XVII rovas e VI libras, item aliam sportam de canella ponderantem incameratam XVII rovas et XVI libras, item aliam sportam de canella ponderantem incameratam XVII rovas et XIIII libras et mediam, item aliam sportam de canella ponderantem incameratam XVIII rovas et II libras, item aliam sportam de canella ponderantem incameratam XVII rovas et IX libras, item aliam sportam de canellam ponderantem incameratam XVIII rovas et IIII libras e mediam, item aliam sportam de canella ponderantem in cameratam XVII rovas et XVII libras. Item in alia butiga III saccos de indio de 
bagadello ponderantes incameratos $\mathrm{X}$ rovas et $\mathrm{XX}$ libras. Item quandam saccam de cotono de Erminia ponderantem cum ipsa sacca XI rovas e mediam libram. Item quandam [...] $/(13 r)$ de Erminia ponderantem cum ipsa sacca VIII rovas et tres libras et mediam, item quandam aliam saccam cotoni de Erminia ponderantem cum ipsa sacca octo rovas, item quandam aliam saccam eiusdem cotoni ponderantem VII rovas XXIII libras et mediam. Item inveni in quadam butiga que est sub scala dicti hospi[...] quendam saccum cotoni de Erminia ponderantem L libras cum suo sacco. Item quandam saccam gale ponderantem [...] sacca XII rovas et XX libras, item aliam saccam gale ponderantem cum ipsa sacca XIII rovas e XX [...], item quandam aliam saccam gale ponderantem cum ipsa sacca VII rovas e XXIII libras, item aliam [...] ponderantem cum sua sacca X rovas et $\mathrm{XX}$ et unam libras. Item inveni unam caxiam de nogerio in qua inveni res sequentes quandam servidoram depictam de opere Bugie, item aliquos trocios cere qui erant circa unam libram cere, item duas brasserolas, item quandam bustiam cum quibusdam fraschis, item quedam scripta papirea modici valoris, item [...] cetras de lautono parvas et tres enses modici valoris, item quasdam tenayes de ferro, item IIII manutergia [...], item quoddam trocium de panno de stupa quod est III canne vel circa, item unum linteamen de lino ruptum, item quandam brasserolam depictam ad signum dicti defuncti. Item inveni quandam aliam caxiam in qua inveni quandam cetram de lautono, item quandam ciphum argenti marchatum marcha Barchinone, item quandam cetram de leutono cum modico de citoval, item quandam bustiam depictam cum zinzebrem quod ponderabat unam libram vel circa, item unum saccetum de canamas in quo erat piper quod erat usque ad VI libras vel circa. Item unum cultellum cum vagina de lautono. Item quedam capibrevia et scripta papirea. Item IIII gots vitri de Domas. Item quandam caxiunculam sive estoig in quo erant quedam balanciete de leutono et quasdam pesalia. Item quedam bustia depicta cum modico de gariofilo et quendam martellum. Item inveni quandam aliam caxiam in qua inveni quasdam coriaceas cum cohoperta de samit virmilio. Item duos bacinetos pisanescos et unam brasserolam pisanescam. Item inveni quandam caxiam parvam in qua erant plura scripta papirea et quedam corrigia alba et quatuor capelli de cirico, item quedam corrigia operata de cirico cum quondam marsupio de cirico et cum quodam ganiveto cum manubrio de ebore et cum vagina de camut. Item XIII duodenas botonorum argenti deauratorum, item unum bacinum parvum. Item inveni quandam aliam caxiam in qua inveni quoddam recoldador de corio, item unum bacinum de leutono, item quandam servidoram depictam de fuste, item unun servidor de palma, item unum tinterium de fuste, item quinque ventayls de palma, item quandam bursam de cirico, item quandam clavam cum manubrio nervorum depicto corroso in quadam sui parte. Item quendam saccum in quo erat piper quod erat usque ad IX libras vel circa. Item inveni quasdam coriaceas cum cooperta in fustanni listati et cum quadam gorgeria cum cooperta fustanni listati, item duas gamberas e duas cuxeras de ferro $/(13 v)[\ldots]$ Item unum bassinetum, item unum capellum armandi de panno lini, item quasdam coriaceas cum cohoperta panni lini. Item quandam atahut in qua inveni VI vanovas panni linei, item unum farcetum de sindone virmilia et tres setras de leutono. Item quandam caxietam de osse in qua inveni quandam coopertam cuxini operatam de cirico et quandam tovalliolam operatam de cirico in eius capicibus, item duas corrigias de cirico munitas de argento, item dua paria de trebugueres et unum marcelletum. Item duas amphoras plenas xarupo, item duas amphoras parvas [...] erat xarupus. Item unum archibanche de tribus caxiis in quarum una inveni unum bassinum de leutono [...] dos barraletos de stanno et quasdam fraschas, item inveni unum saccum in quo inveni decem libras in [...] minucis. In alia vero caxiarum dicti archibanche inveni duo paria balancietarum de leutono cum quibusdam pesalibus alexandrinis et unum galerum sive capell de sol cum corda cirici. Item in alia caxia dicti archibanche inveni octo scutellas magnas de stanno et octo scutellas de stanno parvas et quasdam pixides sive capsas, item inveni quandam caxiunculam in qua inveni octo cloquearia argentea et tres capellos cirici et quendam scripta papirea. Item inveni duo storia. Item quandam caxiam que erat in camera superiori dicti hospicii in qua caxia inveni quendam scripta papirea et quenda martellum et quandam barrinam et III bacinos parvos et quosdam affiblays cirici virmilios veteres aptos ad clamidem hominis, item unum capellum ferri veterem. Item inveni in ipsa camera 
III estoig de corio abtos ad ciphos argenteos conservandos e quandam mensam parvam de fuste. Item IX amphoras parvas de vitro vacuas. Item quandam caxiam de fuste in qua inveni quedam scripta et capibrevia papirea et unum par cirothecarum de corio cervi et quandam frascham. Item invenni in dicto hospicio quandam mensam de fuste, item unum barreganum listatum vetus strictum, item quandam clamidem alamandesch et quoddam supertunicale panni de bifa marbrina coloris viridis cum penna cirogrillorum. Item quandam gramasiam panni mesclat novi cum penna alba cirogrillorum et cum capucio eiusdem panni cum penna de vayres. Item unum rodondell panni lividi. Item quandam gramasiam panni lividi cum penna cirogrilllorum. Item quandam tunicam panni albi. Item quandam gramasiam de camellete cum scindone virmilia. Item quandam tunicam panni lividi. Item aliam tunicam panni viridis. Item unum supertunicale panni virmilii cum penna alba cirogrillorum cum capucio eiusdem panni, Item III barretas unam scilicet panni lividi et aliampanni virmilii et aliam panni mesclat. Item unum cuxinum operatum de cirico. Item septem saccos in quibus erant XXXV quarterie ordei vel circa. Item quandam gabiam aptam ad tenendum papagay. Item inveni in dicto hospicio in quadam domo curtis dicti hospicii duo capeta et unum tranverserium et unum seti et III postes de fuste et unum scutum vetus depictum ad signum dicti deffuncti. Item unum lectum de tabulis cum suo sacrileto et duobus matalafiis et una culcitra et uno pari linteaminum de lino et quandam vanovam et quodam cohopertorium burdi de Alexandria et uno transverserium /(14r) quatuor matalafias et unum scannum et unum seti et unum transverserium et unum tapetum, item unum archibanche cum duabus caxiis scilicet fustem. Item quandam mensam parvam rotundam. Item unum puteale de cupro cum sua cassia. Item inveni unum lectum de tabulis cum suo sacrileto et uno pari linteaminum veterum [...] item unum matalaffium et unum cohopertorium lividam, item quandam flaciatam listatam [...] duo transverseria [...] et quandam catedram sive sedeni de fuste et alium lectum de tabulis cum sacrilecto suo et cum quasdam matalaf[...] et unum pari linteaminum et una vanova veteri et una flaciata et uno cuxino panni lini albi, item duo $[\ldots]$ de pues ferreis qui sunt in uno poste et qui sunt abti ad pectinandum linum. Item unum archibanche de duo caxiis in quarum una inveni duo manutergia, item XVII ramos filati lini crudi, item tres sots(..) cara rosacea et unum par petinorum. Item unum bacinum de leutono cum zucara de pane que erat usque ad duas libras et quandam salseriam de terra cum pulvere zuccare. Item sex manutergia in duabus pecias et unum manutergium et duas mapas et duo linteamina de lino. Item unum lectum tornadis cum suo sacrileto et duas conchas magnas de cupro, quarum una est fracta. Item unum matalafium cum cohoperta de corio et quandam catifam albam. Item unum lavacap de ferro. Item quoddam instrumentum quod vocatur lahut et duos pedes fusteos tabule et quoddam instrumentum quod vocatur guitarra, et unum scannum e quatuor postes fustis et unum sacrilectum et unum par linteaminum et unum cohopertorium vetus et quandam jerram de terra plenam olei continentem usque ad XIIII quartanos. Item unum cavall fust et quatuor sellas et unam flaciatam listatam et unam mensam plicabilem et quandam tinam abta ad balneandum et quosdam ferres putei. Item II catedras sive sedes fustis et duos tripodes ferri et tres cassias de cupro et quatuor calderias de cupro et unum morterium de cupro cum sua manu de cupro et unum forroy ferri et unum capefoguer ferri et quandam mensam de noguerio et duas patellas de cupro et quasdam graticulas sive graelles ferri, item tria verva ferrea et unum cogonare de cupro et unam cetram de leutono veterem et tres locias et quandam conquam parvam et unum morterium de marmore et quandam athaut de fuste veterem. Item duas duodenas scutellarum fusteas, item unam duodenam discorum parvorum et tres discos magnos et unum scannum et unum puteale de cupro. Item quandam pasteriam de fuste cum sua cohoperta fustea. Item duas seccures quarum una est magna et altera parva et duas ciras de fuste in quarum una erant III quarterie farine frumenti et in altera I quarteria farine ordei vel circa. Item inveni unam cetram de leutono et tres duodenas cloqueari[...] parvorum de fuste. $/(14 \mathrm{v})$ Item quandam pasteriam, item II mapas e duo manutergia, item quinque ampullas et unum discum magnum de fuste, item III [...] aptos ad panes portandos. Item II sedacios cirici e I sedacium de sedes, item X jerras de terra vacuas, item XIIII molas de laca de [...]. Item II cubos quorum I continet VI saumatas vindemie vel circa et alterum continet VIII saumatas 
vel circa, item aliud cubum contine[...] VIII saumatas vel circa, item III cubos magnos quorum quilibet continet XIIII saumatas vel circa et duas botas[...] continet I cafficium et medium vel circa et quandam botetam continentem I caficium vel circa, item quatuor botas [...] IX portadoras et I botam magnam et aliam botam magnam quam Subirana soror mea dicit esse suam, item [...] plenam vino continentem II cafficios vel circa, item III botas quarum quelibet continet Il caficia vel circa. Item [...] et duas scalas fustis longas et duas tabulas fustes/, item XI tabulas aptas ad lectum, item quandam marfegam e I banchum $[\ldots]$.... ...

/(16r) finitum fuit hoc inventarium kalendis octobris anno Domini Millesimo Trecentesimo Octavo. Testes huius rei sunt Bernardus Marqueti, Michel Marqueti, Berenguarius de Bossegays, Jacme Basseti, Petrus Tarroch, G. Borrelli, Petrus Figuera e domina Subirana uxor eiusdem Petri Figuera filiaque domine Jacme de Canovis quondam.

\section{9, del 10 d'octubre al 27 de febrer. Barcelona}

Inventari dels béns de Guillem Puig, fet realitzar per la seva vidua Geralda.

Arxiu Capitular de Barcelona, llibre notarial núm. 8 (notari Bernat Vilarrúbias), 84 v. - 86 r.

In Dei nomine noverint universi quod ego Geralda uxor G. de Podio[...] attendens quod dictus maritus meus quondam in suo ultimo testamento dimisit michi usufructum [...] suorum toto [...] prout per testamentum eiusdem mariti mei quondam [...] volens maculam evitare omnisque fraudis suspicionem a me tollere et ne aliqua de bonis existentibus in hereditate dicti mariti mei quondam occultari valeant vel perire die quo computabatur VI idus octobris anno domini M CCC octavo de hiis que inveni in hereditate predicta presens inventarium incepi facere cum hoc venerabili signo cru+cis. Primum inveni in dicta hereditate I lectum scilicet scannum cum suo sacrilecto et uno matalafio listato. Item unum matalafium listatum et unum par linteaminum veterum et unum capciale et unum cohopertorium de burdo et unum sedile since seu. Item inveni quandam athaut magnam scilicet fustem in qua inveni unum par linteaminum et quandam vanovam et tres scapolonos fustanei qui sunt tres cane vel circa. Item inveni unam ciram. Item inveni quandam quantitatem olei que erat in VI jarris que scilicet terra earum erant Guillemoni de podio filii mei que quantitas olei potest esse usque ad LXX quartanos olei in quo oleo idem Guillemonus habebat XX quartanos olei et residum ipsius olei erat dicti G. de Podio quondam mariti mei. Item inveni unum cofinum magnum in quo erat frasca. Item inveni quendam ciphum argenteum intus deauratum et extra marchatum ad marcha Montispesulani ponderantem unam marcham et mediam vel circa. Item quandam athaut veterem scilicet fustem. Item unum supertunicale de panno morato cum penna cirogrillorum quod erat dicti defuncti. Item quandam tunicam veterem de panno livido. Item quandam tunicam veterem de panno albo factam ad usum et servicium corporis mei. Item unum supertunicale de panno virmilio cum penna alba cirogrillorum, item quandam capam de stamme forti virmiliam cum scindone virmilia, item quandam capam de biffa marbrina coloris vidis. Item quandam caxietam sine fons, item quandam cauloriam de cupro fractam. Item duas senallias in quibus erat unam quarteriam seminis spinargiorum, item unum saccum in quo erat aliquantulum de farina ordei, item quandam mensam de noguerio, item unum armarium de fuste vilem. Item quandam taciam argenti marcatam barchinone. Item duas athauts veteres. Item unum morterium de cupro cum sua manu de cupro, item unam cetram de lautono, item quandam concham de aram, item unum transverserium vile et vetus, item quasdam mapas, item duas lanceas, item quandam caulerianes de cupro et quandam cassiam de cupro et quosdam tripodes de ferro et unam patellam ferri non integram et unum veru ferreum, item quandam athaut scilicet fustem, item quandam $/(85 \mathrm{r})$.../...

$/(86 r)$ Item inveni in quodam sacco plura alia instrumenta nullius utilitatis. Item inveni quandam caxietam parvam in qua erant quodam instrumenta modice utilitatis. Item inveni duos cubos continen- 
tes viginti saumatas vel circa, item unum folador continens IIII saumatas vel circa. Item quandam botam continentem tria caficia vel circa, item quandam botam continentem IIII caficia e medium aut circa,item quandam botam continentem tria caficia aut circa, item tres botas quarum quelibet continet unum caficium vel circa, item unam portadoram, item duas barrilas, item duas barrilas veteres .......

Item quinque saccas cotoni quarum due sunt de Ermenia et residue tres sunt de Malta que ponderant inter omnes IIII cargas et mediam vel circa .......

Item inveni in dicta hereditate IX cloqueariam de argento et unum cuxinum operatum cum cirico et unum puteale de cupro sive cassia. Item inveni in dictam hereditatem VI libras monete barchinone predicte quas [...] pro precio trium saccorum de gala qui erant dicti mariti mei quondam quas ego post obitum eiusdem vendidi. Item inveni in dictam hereditate quandam mensuram de cupro que dicitur quarterius et quandam aliam mensuram de cupro que medius quarterius apellantur. Hec que dicta sunt et non alia inveni ad presens in hereditate predictam protestans quod si decetero invenirem aliqua alia bona in dicta hereditate mox faciam inventarium de eisdem. Actum et finitum est hoc inventarium III kalendas marcii, anno Domini M CCC VIII. Testes Jacobus de Ultzina carnifex Berengarius de Piraria cotonerius e Jacobus de Picha carnifex. 